University of California, Hastings College of the Law UC Hastings Scholarship Repository

Faculty Scholarship

2017

\title{
Empirical Evidence of Drug Pricing Games - A Citizen's Pathway Gone Astray
}

Robin Feldman

UC Hastings College of the Law, feldmanr@uchastings.edu

Evan Frondorf

Andrew K. Cordova

Connie Wang

Follow this and additional works at: https://repository.uchastings.edu/faculty_scholarship

\section{Recommended Citation}

Robin Feldman, Evan Frondorf, Andrew K. Cordova, and Connie Wang, Empirical Evidence of Drug Pricing Games - A Citizen's Pathway Gone Astray, 20 Stan. Tech. L. Rev. 39 (2017).

Available at: https://repository.uchastings.edu/faculty_scholarship/1571

This Article is brought to you for free and open access by UC Hastings Scholarship Repository. It has been accepted for inclusion in Faculty Scholarship by an authorized administrator of UC Hastings Scholarship Repository. For more information, please contact wangangela@uchastings.edu. 


\title{
EMPIRICAL EVIDENCE OF DRUG PRICING GAMES-A Citizen's PATHWAY GONE ASTRAY
}

\author{
Robin Feldman, ${ }^{*}$ Evan Frondorf, ${ }^{\dagger}$ \\ Andrew K. Cordova, ${ }^{\ddagger}$ and Connie Wang ${ }^{\S}$
}

CITE AS: 20 STAN. TECH. L. REV. 39 (2017)

\footnotetext{
* Harry and Lillian Hastings Professor and Director of the Institute for Innovation Law, University of California, Hastings College of the Law.

$\dagger$ Research Fellow at the Institute for Innovation Law, University of California, Hastings College of the Law.

$\ddagger$ Executive Director at the Institute for Innovation Law, University of California, Hastings College of the Law.

$\S$ Research Fellow at the Institute for Innovation Law, University of California, Hastings College of the Law. We wish to express our thanks to Matt Avery, Michael Carrier, Scott Hemphill, Cheryl Johnson, Kurt Karst, Mark Lemley, and Daryl Wander for insights and conversations about research methodology. We are also grateful to Grace Bradshaw, Jonathan Cohen, Isil Selen Denemec, Gabriella Gallego, Arya Moshiri, Betty Chang Rowe, Naira Simmons, and Omar Vaquero for research assistance and proof-reading. We wish to particularly thank John Gray, whose data insights played a critical role in the analysis, and Rosie Buchannan, who was instrumental in guiding us through the computer coding process. While the article was in progress, Evan Frondorf completed his position at the University of California Hastings College of the Law, began a full-time position at Stripe, and thus, had to bow out of the final stages. His contributions to the article were immeasurable.

In accordance with the protocols outlined in the Harvard Journal of Law \& Technology Open Letter on Ethical Norms, all of the data is publicly available for future use by other academics on SSRN.com. See Robin Feldman, Evan Frondorf, Andrew K. Cordova, \& Connie Wang, Database from Empirical Evidence of Drug Pricing Games-A Citizen's Pathway Gone Astray, SSRN (Mar. 7, 2017) https://papers.ssrn.com/sol3/papers.cfm?abstract_id=2924673 [http://perma.cc/B8S4-PEYH]. See also Robin Feldman, Mark A. Lemley, Jonathan S. Masur, \& Arti K. Rai, Open Letter on Ethical Norms in Intellectual Property Scholarship, 29 HARVARD J.L. \& TECH. 339 (2016) (signed by dozens of professors). In further accord with the Open Letter, the University of California Hastings Institute for Innovation Law, which Robin Feldman directs, has made donation information available. Donors, INST. FOR INNOVATION L.: UC HASTINGS COLLEGE OF L. (May 3, 2017), http://innovation.uchastings.edu/about/funding/funding-for -academic-year-2015-2016 [http://perma.cc/EK2K-XB72]. No private or corporate donor accounts for more than $10 \%$ of the Institute's budget.
} 


\begin{abstract}
The Food and Drug Administration's citizen petition process was created in the 1970s as part of an effort to fashion more participatory regimes, and was intended as a mechanism for ordinary citizens to raise concerns about food, drugs, and FDA regulations. Anecdotal evidence suggests, however, that the citizen petition process may have taken a different turn. This empirical study explores whether pharmaceutical companies are systematically using citizen petitions to try to delay the approval of generic competitors. Delaying generic entry of a drug-even by a few months - can be worth hundreds of millions of dollars of additional revenue, a cost ultimately borne by consumers and government agencies in the form of high drug prices.

This Article provides empirical evidence that the citizen petition process at the FDA has now become a key avenue for strategic behavior by pharmaceutical companies to delay entry of generic competition. It is a far cry from the "participatory citizen" notion that fueled the creation of such avenues at regulatory agencies. Not only has the number of citizen petitions with the potential to delay generic entry dramatically increased over the past decade, but the timing of citizen petitions indicates that they are being filed late in the game as a last-ditch effort to hold off competition. Congressional reforms enacted in 2007 aimed to stem the tide of citizen petition abuse, but our analysis of the data indicates that those reforms have not succeeded in doing so. This Article concludes by examining the nature of the problem and exploring the feasibility of three types of approaches to curb the behavior. These include: 1) a simple prohibition, if one were to conclude that most behavior in the category is likely to be inappropriate; 2) procedural blocks to ensure that the behavior cannot create suboptimal results; or 3) punitive measures as a deterrent.
\end{abstract}


TABLE OF CONTENTS

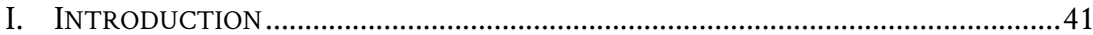

II. THE GENERIC DRUG PROCESS AND HISTORIC EFFORTS AT DELAY .....................46

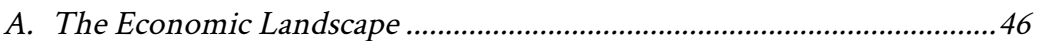

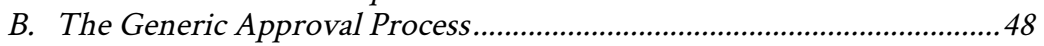

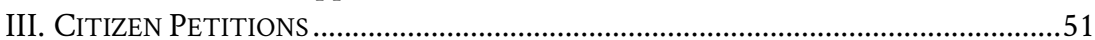

A. Troubling Behavior in the Citizen Petition Process ................................52

B. Changes to the FDA Citizen Petition Process .........................................54

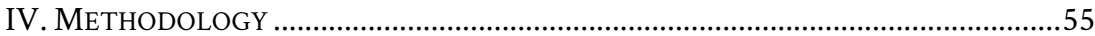

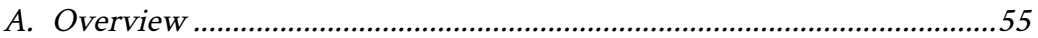

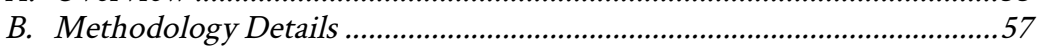

1. Compiling All Citizen Petitions Filed Since 2000 ..............................57

2. Identifying Citizen Petitions that Could Delay Generic

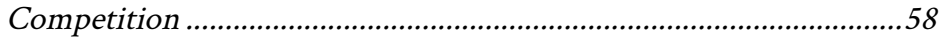

a. Removing Citizen Petitions Unrelated on Their Face ................58

b. Removing Citizen Petitions Unrelated Based on Their

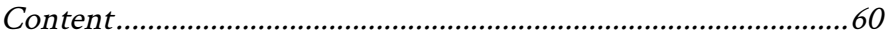

c. The Final Citizen Petition Pool ....................................................62

3. Timing of the Citizen Petitions Relative to Generic Applications...64

a. Filing Dates for Generic Applications .........................................64

b. Matching Citizen Petitions to Relevant Applications ................67

c. Establishing Key Metrics .........................................................69

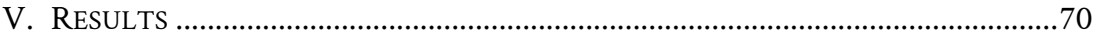

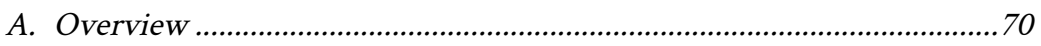

B. Rise in Citizen Petitions with the Potential to Delay..............................71

C. When Are Citizen Petitions Filed in Relation to Final Approval?..........72

D. When Are Citizen Petitions Filed as a Percentage of the Total Application Time? .78

E. Did the 2007 Amendments Do the Job? .............................................. 82

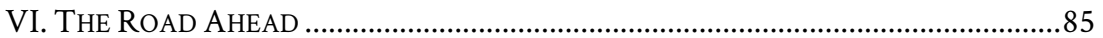



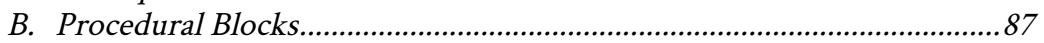

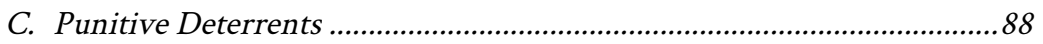

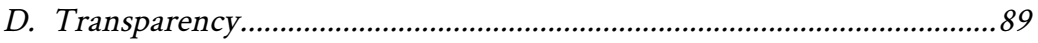

\section{INTRODUCTION}

For thirty years, the Hatch-Waxman system for expediting approval of generic drugs has brought increased competition to the market and lower drug prices to consumers of all income levels. The generic approval system has enjoyed extraordinary success. Today, more than $80 \%$ of prescriptions are filled with 
generics, ${ }^{1}$ and most generics are eventually priced at a discount that is 80-85\% below their brand-name equivalents. ${ }^{2}$ Despite this success, anecdotal evidence has percolated in recent years about new forms of strategic behavior designed to keep drug prices artificially inflated by blocking generic entry. ${ }^{3}$

In particular, public outcry over the rising price of pharmaceuticals has led to highly publicized congressional hearings, high profile press articles, and outrage from various presidential candidates on the topic. These public forays reveal examples of disturbing behaviors in various corners of the pharmaceutical industry. For example, the nation was riveted when the Turing CEO Martin Shkreli appeared before Congress regarding his company's elevation of a drug price from $\$ 13.50$ a tablet to $\$ 750$ a tablet, a price hike apparently protected by efforts to block out generic competitors. ${ }^{4}$ In a similar vein, federal prosecutors have initiated a fraud action against the pharmaceutical company Valeant for tactics related to specialty pharmacies and price increases. ${ }^{5}$

1. See Implementation of the Generic Drug User Fee Amendments of 2012 (GDUFA): Hearing Before the H. Comm. on Oversight \& Gov't Reform, 114th Cong. 1 \& chart 1 (2016) [hereinafter Hearing] (statement of Janet Woodcock, Dir., Ctr. for Drug Evaluation \& Research, FDA), https://www.fda.gov/NewsEvents/Testimony/ucm485057.htm [http://perma.cc/XRP7D4P6]; see also IMS InST. FOR HEALTHCARE INFORMATICS, MEDICINE USE AND SHIFTING COSTS OF HEALTHCARE: A REVIEW OF THE USE of MEdicines IN THE UNITED STATES IN 201351 (Apr. 2014), http://www.imshealth.com/en/thought-leadership/ims-institute/reports/use-of-medicines-inthe-us-2013\#ims-form [http://perma.cc/RX4V-LXST].

2. See Facts About Generic Drugs, U.S. Food \& Drug Admin. (June 28, 2016), http://www.fda.gov/Drugs/ResourcesForYou/Consumers/BuyingUsingMedicineSafely /UnderstandingGenericDrugs/ucm167991.htm [http://perma.cc/GQ92-QEN4] [hereinafter Facts].

3. See, e.g., Robin Feldman \& Evan Frondorf, Drug Wars: A New Generation of Generic Pharmaceutical Delay, 53 HARV. J. ON LEGIS. 499, 524-54 (2016) (describing what the authors call "Generation 3.0" tactics that use administrative processes, regulatory schemes, and drug modification to block or delay generic entry into the market).

4. For details of how the Turing system was designed, see Feldman \& Frondorf, supra note 3, at 536-38. See also Andrew Pollack, Drug Goes from \$13.50 a Tablet to \$750, Overnight, N.Y. TIMES (Sept. 20, 2015), http://www.nytimes.com/2015/09/21/business/a-huge-overnight -increase-in- a-drugs-price-raises-protests.html [http://perma.cc/F26V-JSKR]. The price of the drug was as low as $\$ 1$ in 2010, before a series of acquisitions. Id.; Andrew Pollack, New York Attorney General Examining Whether Turing Restricted Drug Access, N.Y. TIMES (Oct. 12, 2015), http://www.nytimes.com/2015/10/13/business/new-york-attorney-general-examining -if-turing-restricted-drug-access.html [http://perma.cc/CTF6- DSNL]; Michael Carrier \& Aaron Kesselheim, The Daraprim Price Hike and a Role for Antitrust, Health AfFairs Blog (Oct. 21, 2015), http://healthaffairs.org/blog/2015/10/21/the-daraprim-price-hike-and-a-rolefor-antitrust [http://perma.cc/3Z7V-DQ6C]; Ed Silverman, How Martin Shkreli Prevents Generic Versions of His Pricey Pill, Pharmalot (Oct. 5, 2015), http://pharmalot.com/how -martin-shkreli-prevents-generic-versions-of-his-pricey-pill [http://perma.cc/U78B-U6YE].

5. Feldman \& Frondorf, supra note 3, at 538-39; see also Bertrand Marotte, Valeant's Sales Network: Deciphering a Complex Web of Companies, Globe \& Mall (Oct. 27, 2015), http://www.theglobeandmail.com/report-on-business/valeants-sales-network-the-firms-and -chess-terms-tied-to-it/article27009058 [http://perma.cc/9D3F-9HJ8]; Jacquie McNish, et al., U.S. Attorney Charges Former Valeant, Philidor Executives, Alleging Fraud and Kickback Scheme, WALL ST. J. (Nov. 17, 2016), https://www.wsj.com/articles/u-s-attorney-to-charge -two-valeant-philidor-executives-alleging-fraud-and-kickback-scheme-1479394276 
One can understand the motivation behind such behavior. Delaying generic entry for a blockbuster drug-even by just a few months-can be worth hundreds of millions of dollars of additional revenue. ${ }^{6}$ To offer a simplistic example, Gilead's Hepatitis C Drug, Sovaldi, was the top-selling drug in the United States in 2014, with $\$ 7.9$ billion in sales. ${ }^{7}$ Three additional months at that rate would constitute $\$ 1.98$ billion in sales. ${ }^{8}$ In fact, 55 drugs in the United States earned more than $\$ 1$ billion in sales in 2013. ${ }^{9}$ Three more months at that rate would constitute more than $\$ 300$ million in sales for each company.

The dollars at stake create a powerful incentive to keep searching for new pathways to delay generic competition. From society's standpoint, one would prefer that companies search for pathways of treating human disease, rather than pathways of blocking competition. Thus, the process of exposing and shutting down avenues for generic delay is critical for keeping the generic system properly on track.

With the anecdotes described above, as well as recent scholarship, ${ }^{10}$ concerns have swirled around the citizen petition process at the Food \& Drug Administration (FDA). The FDA's citizen petition process was created in the 1970s, along with similar programs at other agencies, and was intended to fashion more participatory regimes, in which ordinary citizens could access the administrative process. ${ }^{11}$ The theoretical underpinnings hypothesized that a participatory structure would prevent regulatory agencies from being captured by the very industries they were designed to police. Recent evidence suggests, however, that the FDA's citizen petition process may have taken a different turn. We set out to analyze the issue.

[http://perma.cc/JW5C-XSSN]; Katie Thomas \& Matthew Goldstein, Former Drug Industry Executives Charged in Kickback Scheme, N.Y. Times (Nov. 17, 2016), https://www.nytimes.com /2016/11/18/business/valeant-philidor-fraud-kickback-scheme.html? r=2 [http://perma.cc /ZL28-55EK]; Roddy Boyd, The King's Gambit: Valeant's Big Secret, S. InVESTIGATIVE REPORTING FOUND. (Oct. 19, 2015), http://sirf-online.org/2015/10/19/hidden-in-plain-sightvaleants-big-crazy-sort-of-secret-story [http://perma.cc/N34K-B8TQ].

6. See Feldman \& Frondorf, supra note 3, at 503 n.23 (detailing examples).

7. Lacie Glover, Here Are the Top-Selling Drugs in the US, TIME (June 26, 2015), http://time.com/money/3938166/top-selling-drugs-sovaldi-abilify-humira/?xid=soc _socialflow_twitter_money [http://perma.cc/C58U-PFZP].

8. Although competition would not reduce the sales to zero, a price drop of even a modest $10 \%$ would be worth $\$ 198$ million for three months.

9. U.S. Pharmaceutical Sales-2013, DrUGS.COM (Feb. 2014), http://www.drugs.com /stats/top100/2013/sales [http://perma.cc/3Q4Z- TVZT].

10. See generally Michael Carrier \& Daryl Wander, Citizen Petitions: An Empirical Study, 34 CARDOZO L. REV. 249 (2012); Feldman \& Frondorf, supra note 3.

11. The following germinal texts describe the movement and debate its consequences. Christopher EdLEy, JR., ADMinistrative LAW: RETHINking JUdicial CONTROL OF BureauCRACY (1990); Clark Byse, Vermont Yankee and the Evolution of Administrative Procedure, 91 HaRV. L. REV. 1823 (1978); Antonin Scalia, Vermont Yankee: The APA, the D.C. Circuit, and the Supreme Court, 1978 Sup. Cт. Rev. 345 (1978); see also Reuel R. Schiller, Rulemaking's Promise: Administrative Law and Legal Culture in the 1960s and 1970s, 53 ADMIN. L. ReV. 1139 (2001); Sidney A. Shapiro \& Richard W. Murphy, Eight Things Americans Can't Figure Out About Controlling Power, 61 Admin. L. ReV. 5 (2009); Paul R. Verkuil, The Wait Is Over: Chevron as the Stealth Vermont Yankee II, 75 GEO. WASH. L. REV. 921 (2007). 
From an empirical perspective, we aimed to explore whether pharmaceutical companies are systematically using citizen petitions to try to delay FDA approval of generic competitors. To do this, we looked at the timing of when citizen petitions are filed by competitors during the approval process for generic drugs, as well as trends across time for this type of filing. We were looking for evidence that such petitions are being used as a last-ditch effort to delay generic entry as long as absolutely possible.

Assembling this information was difficult, to say the least. As with all information about strategic behavior in pharmaceutical pricing, it must be painstakingly pieced together from scattered and incomplete public records. The Article below describes the extensive research undertaken to assemble this picture of a citizen's pathway being used by drug companies as a delay tactic.

It is a remarkable picture, indeed. Following are the key findings from the study:

- The FDA's citizen petition pathway is one of the key pathways involved in the modern generation of generic drug delay, playing a role in various game-playing strategies.

- Citizen petitions from competitor companies-brand names and generics seeking to delay competitors-have essentially doubled since 2003.

- Citizen petitions with the potential to delay generic entry have constituted a striking portion of the citizen petitions in recent years. Out of all citizen petitions filed at the FDA between 2000 and 2012 (including those concerning tobacco, food, dietary supplements, medical devices, etc.), nearly $15 \%$ had the potential to delay a generic drug application, climbing to $20 \%$ in some years.

- Many citizen petitions in our data set appear to be a last-ditch effort to hold off generic competition. In fact, the most common category of all generic-related petitions was petitions filed within six months of generic approval. This is particularly striking given that the overwhelming majority of citizen petitions are denied. ${ }^{12}$ In other words, the results suggest that many competitor petitions are filed late in the game as a final effort to hold off competition just a little longer, even though they are unlikely to be successful.

- Congressional reforms enacted in 2007 have not stemmed the tide of such delay-related petitions.

12. See Michael A. Carrier \& Carl Minniti, Citizen Petitions: Long, Late-Filed, and AtLast Denied, 66 AM. U. L. Rev. 305, 332-33, 333 tbl. 4 (2016) (finding that between 2011 and 2015, the FDA denied $92 \%$ of section 505(q) citizen petitions, the type most often employed to oppose generic entry); Carrier \& Wander, supra note 10, at 249, 274, 274 tbl.3 (finding that the FDA denied $81 \%$ of citizen petitions filed by competitors against drug companies between 2001 and 2010). 
The study provides empirical evidence that the citizen petition process at the FDA has now become a key avenue for strategic behavior by pharmaceutical companies to delay entry of generic competition. Why now? The answer is simple. For decades, pharmaceutical companies had a favored avenue for delaying generic competition. Courts have been slowly shutting down this technique, known as payfor-delay, in response to cases filed by the Federal Trade Commission and generic companies. With the handwriting on the wall, pharmaceutical companies have looked for other methods of delay. Our results show that the citizen petition process has become a key alternative. It is a far cry from the "participatory citizen" notion that fueled the creation of such avenues at regulatory agencies.

As described above, the delay achieved through a citizen petition, even if the petition is eventually denied, can be worth hundreds of millions of dollars in revenue for a drug company. The burden of that increased cost ultimately falls on consumers and the economy. ${ }^{13}$ Thus, this Article provides critical evidence for legislators and regulators in their efforts to ensure adequate competition and appropriate pricing in the health care sector. Following the protocols outlined in the Harvard Journal of Law \& Technology Open Letter on Ethical Norms, ${ }^{14}$ we are making all of our data public for future use by other academics.

Part I of this Article briefly describes the process for generic drug entry and details waves of tactics used in the past to block or delay the entry of generic competition. Part II explains the regulatory history of citizen petitions, focusing on changes to the process over time. Citizen petitions have long been a source of consternation for the FDA and other agencies, and a number of modifications have been made to the petitioning process in the hopes of curbing abuse, albeit with mixed success. These changes will factor into our quantitative analysis, as we split our data into periods divided by major changes to the citizen petition regulations.

Part III describes, in detail, the methodology we used to obtain and identify all citizen petitions between 2000 and 2012 related to generic drugs, as well as every generic drug application approved between 2006 and 2015. These two data sets were then used to "match" citizen petitions with the most relevant generic drug application potentially affected by the petition, setting the stage for a comparison of when citizen petitions are filed relative to when generic drug applications are filed and approved.

Part IV presents the results of our study, including descriptive statistics about the citizen petitions and generic drug applications we collected. We use dates from citizen petitions and generic drug applications to construct "timing" metrics that show the time that passes between when the generic application was filed and when the competitor's citizen petition was filed, as well as between when the competitor's citizen petition was filed and when the generic application was approved, among other calculations.

Part V concludes by examining the nature of the problem and exploring three possible approaches to curb the behavior. These include: 1) a simple prohibition, if

13. See infra text accompanying notes 15-16.

14. See Feldman et al., Open Letter, supra note §, at 346-49. 
one were to conclude that most behavior in the category is likely to be inappropriate; 2) procedural blocks to ensure that the behavior cannot create suboptimal results; or 3) punitive measures as a deterrent. Part V also includes recommendations regarding issues in FDA data collection and transparency.

\section{The Generic Drug Process AND Historic EFForTs AT DELAY}

\section{A. The Economic Landscape}

The advent of generic drugs in the United States has been one of the most significant sources of cost savings in modern health care. Specifically, the FDA estimates that consumers saved \$254 billion in 2014 through generic competition, and achieved a total of $\$ 1.68$ trillion of savings in the decade between 2005 and $2014 .^{15}$ The staggering cost reductions are the result of both widespread availability of generic drugs and the deep discounts that result in markets with generic competition. Over $80 \%$ of small-molecule drugs have generic equivalents, and more than $80 \%$ of all prescriptions are filled using generic medication. ${ }^{16}$ After generic competition begins, the price of most drugs eventually falls to $80-85 \%$ below the original brand-name cost. ${ }^{17}$

Brand-name drug companies, who enjoy a monopoly in the market for a drug until generic entry, face a nearly instant plummet in market share and price. Considering that generic entry often coincides with the expiration of a brand-name company's patents or FDA exclusivities, it is no surprise that looming generic competition is often referred to as the "patent cliff." ${ }^{18}$ It is also not surprising that patent holders try to prevent falling into the approaching chasm using any means possible.

Early delay tactics, still in play today, focused on settlements between brandname companies and potential generic entrants. As described below, the process for generic approval involves a detailed and stylized dance between original drug makers and their would-be competitors, which often results in litigation over the validity of the patent on the original drug or its application to the generic entrant. ${ }^{19}$

15. Generic Pharm. Ass'N, Generic Drug SAVings IN THE U.S. 1 (2015), http://www.gphaonline.org/media/wysiwyg/PDF/GPhA_Savings_Report_2015.pdf [http:// perma.cc/6YUR-9SVU] (data supplied by IMS Institute for Healthcare Informatics); see Hearing, supra note 1, at 1 (statement of Janet Woodcock, Dir., Ctr. for Drug Evaluation \& Research, FDA).

16. See Hearing, supra note 1, at 1 (statement of Janet Woodcock, Dir., Ctr. for Drug Evaluation \& Research, FDA); IMS INST. FOR HEALTHCARE INFORMATICS, supra note 1, at 51; Ernst R. Berndt \& Murray L. Aitken, Brand Loyalty, Generic Entry and Price Competition in Pharmaceuticals in the Quarter Century After the 1984 Waxman-Hatch Legislation 6 (Nat'1 Bureau of Econ. Research. Working Paper No. 16431, 2010), http://www.nber.org/papers /w16431.pdf [http://perma.cc/XY26-RBY6].

17. See Facts, supra note 2.

18. See, e.g., Carrier \& Wander, supra note 10, at 253 (using the term "patent cliff").

19. See infra text accompanying notes 27-40. 
In the course of such litigation, some brand and generic companies have settled their disputes by entering into so-called "pay-for-delay" or "reverse payment" agreements, in which a generic applicant agrees to stay out of the market for a certain period of time in exchange for cash and other considerations. These deals often lead to years of delay and increased revenue valued in the hundreds of millions of dollars. ${ }^{20}$ From a litigation perspective, these agreements are unusual because they represent a transfer of value from a patent holder to an accused infringer. In contrast, lawsuits generally settle when the accused party agrees to pay an amount to the complaining party.

The companies have argued that such settlements represent a reasonable assessment of the cost of continuing litigation and risks of losing a case, no matter how strong one's position may be. Antitrust scholars and competition authorities have raised concerns, however, that such agreements allow the parties to keep prices artificially high and then share the resulting monopoly rents. ${ }^{21}$ Brand-name companies are able to preserve years of monopoly sales, and generics receive a share of those profits from the settlement payment, generally worth more than what the generic might make in a duopoly or in a competitive market.

Most importantly, with benefits provided under Hatch-Waxman to the first generic filer, a pay-for-delay agreement frequently serves as a roadblock to any other competitors, preserving the monopoly-rent environment. In light of these effects, the Federal Trade Commission (FTC) has estimated that reverse payment settlements cost consumers upwards of $\$ 3.5$ billion each year. ${ }^{22}$

After years of debate and scrutiny of reverse payment settlements, the Supreme Court entered the conversation in FTC v. Actavis. ${ }^{23}$ While declining to find payfor-delay agreements presumptively illegal, the Court allowed an FTC case challenging a reverse payment to go forward and outlined a number of reasons why reverse payment settlements should be open to antitrust scrutiny. ${ }^{24}$ In the antitrust world, where the law moves at a glacial pace, the Supreme Court's pronouncement

20. For a more detailed explanation and history of delay tactics, see Feldman \& Frondorf, supra note 3.

21. See generally Robin Feldman, Rethinking Patent Law (2012); Matthew Avery \& Mary Nguyen, The Roadblock for Generic Drugs: Declaratory Judgment Jurisdiction for Later Generic Challengers, 15 N.C. J.L. \& TECH. 1 (2013); Jessie Cheng, An Antitrust Analysis of Product Hopping in the Pharmaceutical Industry, 108 ColuM. L. REV. 1471 (2008); Stacey L. Dogan \& Mark A. Lemley, Antitrust Law and Regulatory Gaming, 87 TEX. L. REV. 685 (2009); Feldman \& Frondorf, supra note 3; C. Scott Hemphill, An Aggregate Approach to Antitrust: Using New Data and Rulemaking to Preserve Drug Competition, 109 Colum. L. ReV. 629 (2009); C. Scott Hemphill, Paying for Delay: Pharmaceutical Patent Settlement as a Regulatory Design Problem, 81 N.Y.U. L. REV. 1553 (2006); Steve D. Shadowen, Keith B. Leffler \& Joseph T. Lukens, Anticompetitive Product Changes in the Pharmaceutical Industry, 41 RUTGERs L.J. 1 (2009).

22. See Fed. Trade Comm'n, Pay-For-Delay: How Drug Company Pay-Offs Cost CONSUMERS BILLIONS 2 (2010), https://www.ftc.gov/reports/pay-delay-how-drug-company -pay-offs-cost-consumers-billions-federal-trade-commission-staff $\quad$ [http://perma.cc/N3XY -MQJE].

23. Fed. Trade Comm'n v. Actavis, Inc., 133 S. Ct. 2223 (2013).

24. Id. 
was the equivalent of a minor temblor. ${ }^{25}$ The shock waves have filtered slowly through the lower courts as those courts have shaped the contours of antitrust analysis and ruled on what kinds of agreements should be subject to scrutiny. In particular, pharmaceutical companies have developed agreements far more complex than what the Supreme Court ruled on in Actavis, including ones that eliminate pure cash payments and provide consideration such as promotional deals, licensing agreements, research and development deals, and the settlement of multiple cases at once.

Although the topic continues to percolate through the courts, pay-for-delay agreements appear to be on the decline. In the first full year after the Actavis decision, fiscal year 2014, the FTC labeled 21 settlements as potential pay-for-delay deals, down from 29 in fiscal year 2013 and the record high of 40 in fiscal year $2012 .^{26}$

With settlements between brand-name companies and prospective generics coming under this substantial scrutiny in recent years, pharmaceutical companies have turned to new tactics to delay generic entry. These strategies make use of public FDA petition processes, inconsequential labeling changes, slight tweaks to existing drugs and formulations, and disingenuous safety concerns, among others, to block generic competition and obtain additional months of monopoly power. The move has been from collaboration with generic drug makers to obstruction of them. Even if these tactics are likely to fail in constructing a permanent generic blockade, they are relatively costless and easy to attempt; and even if they only secure a few months of last-ditch delay, those precious few months could still be worth hundreds of millions of dollars, given that top-selling drugs may exceed \$1 billion in U.S. sales annually. The strategy is similar to futile measures to slow a sinking ship by tossing everything overboard; the outcome is essentially inevitable, but the timing is malleable. In this case, slowing submersion, even marginally, can be extremely valuable.

\section{B. The Generic Approval Process}

Understanding pharmaceutical game-playing techniques requires at least a basic understanding of the process for approval of generic drugs. ${ }^{27}$ The passage of

25. See Robin Feldman, Ending Patent Exceptionalism and Structuring the Rule of Reason: The Supreme Court Opens the Door for Both, 15 Minn. J.L. SCI. \& TECH. 61, 63, 74-76 (2014); see also Michael A. Carrier, Payment After Actavis, 100 Iow A L. ReV. 7, 8-9, 47-49 (2014); Aaron Edlin et al., Activating Actavis, 28 AnTitrust 16, 16 (2013).

26. See Bureau of Competition, Fed. Trade Comm'n, Agreements Filed with the Federal Trade Commission under the Medicare Prescription Drug, Improvement, and

$\begin{array}{llllll}\text { MODERNIZATION ACT } & \text { OF } & 2003 & 3 & \text { (2016), }\end{array}$
https://www.ftc.gov/system/files/documents/reports/agreements-filled-federal-tradecommission-under-medicare-prescription-drug-improvement/160113mmafy14rpt.pdf [http://perma.cc/X66Q-HV4H].

27. For a detailed description of the Hatch-Waxman process for approval of generic drugs, see generally Matthew Avery, Continuing Abuse of the Hatch-Waxman Act by Pharmaceutical 
the Hatch-Waxman Act in 1984 ushered in the modern era of generic medication through a number of regulations designed to ease the path of generics to the market. $^{28}$ The Act introduced the concept of the Abbreviated New Drug Application, commonly referred to as an "ANDA," which allows prospective generics to use existing clinical trial data to obtain approval of a drug bioequivalent to an existing drug. The development process can be completed without the threat of a patent infringement suit from the drug company already on the market.

Although the term "ANDA" is familiar to those in the life science industry, we use the term "generic drug application" in most places, to avoid the confusion of a paper littered with insider acronyms. As one of the authors has noted in the past, writing in clear, simple language presses legal actors to be faithful to supportable logic, rather than subject to the whims of prejudice masked in obscurity. ${ }^{29}$

In addition to an expedited approval process, Hatch-Waxman offers incentives for generics to challenge weak or invalid patents protecting drugs already on the market. The process begins with what is known as the "Orange Book." When an original drug maker applies to the FDA for approval, the company is required to identify all patents protecting the drug. That list is publicized in an FDA document commonly known as the "Orange Book," in reference to the orange cover on each volume. $^{30}$

When a generic company applies for permission to make a generic version of the drug down the road, it must make a certification in relation to each of the patents listed in the Orange Book, declaring, among other options, that the patent is expired, that the patent is irrelevant, or that the applicant will not enter the market until the expiration of the patent. ${ }^{31}$ One category of certifications, however, holds most of the action. So-called "Paragraph IV" certifications declare that one of the patents listed in the Orange Book is either invalid or will not be infringed by the generic drug application. ${ }^{32}$ A Paragraph IV certification initiates a stylized dance between the parties that generally results in litigation. ${ }^{33}$

The process contains an incentive to encourage generic applicants to file

Patent Holders and the Failure of the 2003 Amendments, 60 Hastings L.J. 171, 178, 178 nn.5556 (2008); Cheng, supra note 21; Feldman, supra note 21, at 158-78; Feldman \& Frondorf, supra note 3; Hemphill, Paying for Delay, supra note 21.

28. Drug Price Competition and Patent Term Restoration Act, Pub. L. No. 98-417, 98 Stat. 1585 (1984) (codified as amended in scattered sections of 21 U.S.C. and 35 U.S.C.).

29. See Robin Feldman, The Role of Science In Law 180 (2009) (excerpted in Robin Feldman, Plain Language Patents, 17 TeX. InTELl. Prop. L.J. 289 (2009) and discussing the dangers that arise when legal actors cloak themselves in scientific jargon); see also FELDMAN, THE ROLE OF SCIENCE IN LAW 5-7, 174-95 (exploring the issue further).

30. The formal name of the Orange Book is "Approved Drug Products with Therapeutic Equivalence Evaluations." Orange Book: Approved Drug Products with Therapeutic Equivalence Evaluations, U.S. FOOD \& DRUG ADMIN. (Sept. 2016), http://www.accessdata.fda.gov /scripts/cder/ob/default.cfm [http://perma.cc/AU6U-XFWY].

31. 21 U.S.C. $\$ 355(\mathrm{j})(2)(\mathrm{A})(\mathrm{vii})(\mathrm{I})-(\mathrm{III})$ (2012 \& Supp. III 2015).

32. Id. §355(j)(2)(A)(vii)(IV).

33. See generally sources cited supra note 27 . 
Paragraph IV certifications declaring that one of the original drug maker's patents is invalid or invalidly applied. The first generic company to submit such a certification is, with some stipulations, entitled to six months of marketing exclusivity for the generic drug, as long as the generic does not lose its patent infringement case. ${ }^{34}$ Thus, the first generic that meets this criteria will be the only competitor to the brand-name drug for its first six months on the market, a period that can be worth hundreds of millions of dollars in sales for the generic. ${ }^{35}$ The benefit reflects concern over the presence of invalid patents within the system and is intended to give generic companies an incentive to battle with pharmaceutical companies whose patents are weak or applied to the wrong product. ${ }^{36}$

Data on the results of Paragraph IV court cases confirm the presence of weak patents within the life science arena and the importance of the Paragraph IV process. For example, an FTC study of all such cases resolved on the merits between 1992 and 2002 found that the generic company prevailed $73 \%$ of the time. ${ }^{37}$

Cases resolved on the merits represent only a portion of the Paragraph IV certifications. ${ }^{38}$ Nevertheless, the FTC study offers striking evidence that, like high tech, life sciences also must worry about weak patents. ${ }^{39}$

34. 21 U.S.C. $\$ 355(j)(5)(B)(i v)$. After 2003 amendments to Hatch-Waxman, it is possible to forfeit the 180-day exclusivity period without losing a patent infringement case when certain criteria are met, such as a failure to market the generic within a certain period of time. Id. $\S 355(\mathrm{j})(5)(\mathrm{D})$. Further, it is also possible that the brand-name drug company chooses not to bring litigation during the forty-five-day period. In this case, the first-filer still retains its rights to 180 days of exclusivity.

35. In fact, sales during this period can represent the majority of profits that can be potentially gained from generic entry. Avery, supra note 27 , at $178 \mathrm{nn} .55-56$. As the number of competitors in a market increases, the price drops to the point where it approaches the marginal cost of producing the drug, thus nearing perfect completion and minimizing the amount of profit that any one seller can obtain. During the 180-day period, the FDA is not permitted to approve any other generic applications that have a Paragraph IV certification. 21 U.S.C $\S 355(\mathrm{~J})(5)(\mathrm{B})(\mathrm{iv})(\mathrm{I})-(\mathrm{II})$. However, this does not entirely prevent the presence of other competition. Brand-name companies have developed a technique in which they launch their own generic version of the drug at a lower price tier (or permit another company to do so), creating instant competition for the generic. These generics are often called "authorized generics." See Fed. Trade Comm'n, Authorized Generic Drugs: Short-Term EfFects and Long-Term IMPACT i (2011), http://www.ftc.gov/os/2011/08/2011genericdrugreport.pdf [http://perma.cc /P5EX-NKJR]; Feldman \& Frondorf, supra note 3, at 522-24 (describing authorized generics in detail).

36. See Feldman, supra note 21 , at 161.

37. Fed. Trade Comm'n, Generic Drug Entry Prior to Patent Expiration: An FTC STUDY 16 (2002), https://www.ftc.gov/sites/default/files/documents/reports/generic-drug -entry-prior-patent-expiration-ftc-study/genericdrugstudy_0.pdf $\quad[\mathrm{http}: / /$ perma.cc/MF3N -MDMZ].

38. Cf. Robin Feldman, Tom Ewing \& Sara Jeruss, The AIA 500 Expanded: The Effects of Patent Monetization Entities, 18 UCLA J.L. \& TECH. 1, 59-60 (2013) (empirical study of roughly 13,000 patent lawsuits across four years showing, among other findings, that most patent lawsuits settle prior to a decision on the merits).

39. See FELDMAN, supra note 21, at 170-77 (discussing the practice of attempting to refresh one's patents by patenting extended release versions, alternative delivery methods, or other variations of the original product-a practice known as "evergreening"). 
Hatch-Waxman led to the rapid proliferation of generics. The complexity of the system also created an environment ripe for abuse. From the pay-for-delay deals described above to other manipulations, courts, legislators, and regulators have engaged in an endless game of cat-and-mouse to close off avenues for manipulation as they are uncovered. ${ }^{40}$ The road now leads to the lowly citizen petition.

In Drug Wars: A New Generation of Generic Pharmaceutical Delay, authors Feldman and Frondorf refer to the idea of "Generation 3.0"-this most recent collection of generic delay strategies, connected by their efforts at obstruction of generics rather than collaboration between pharmaceutical companies. ${ }^{41}$ Our survey of all citizen petitions filed between 2000 and 2012 makes it clear that citizen petitions do not represent just one of these strategies; rather, petitions are the gateway to many identified forms of delay. Labeling changes that create more work for generics, requests to institute a safety-related "REMS" program of restricted distribution for a drug-many of these tactics are initiated through citizen petitions. $^{42}$ Thus, short, cheap filings with the FDA-citizen petitions-are perhaps the most prominent way that small-scale, obstructionist delay is effectuated today.

\section{CITIZEN PETITIONS}

The citizen petition process was mandated by Congress' passage of the Administrative Procedure Act, which requires federal agencies to create a formal route for the public to petition an agency to change, amend, or repeal an agency rule. $^{43}$ As described above, the FDA's citizen petition process can be traced back to the 1970s, a period in which courts and policy-makers encouraged the creation of pathways so that ordinary citizens could engage in the administrative process taking place at regulatory agencies. ${ }^{44}$ The FDA's process allows petitioners to "request the Commissioner of Food and Drugs to ... (issue, amend, or revoke a regulation or order or take or refrain from any other form of administrative action)." ${ }^{45}$ Petitions

40. See generally Feldman \& Frondorf, supra note 3 (describing three generations of strategies used by brand-name companies to deter and delay generic entry, along with administrative changes and congressional amendments that have tried, and failed, to keep pace).

41. See generally Feldman \& Frondorf, supra note 3, at 524.

42. "REMS" is an abbreviation for Risk Evaluation and Mitigation Strategies. The REMS program was instituted as part of the 2007 Food \& Drug Administration Amendments Act. It gives the FDA the authority to require drug manufacturers to produce a REMS, essentially a set of safety strategies, when the potential risks of a medicine are a concern. See FDA Basics Webinar: A Brief Overview of Risk Evaluation and Mitigation Strategies (REMS), U.S. FOOD \& DRUG ADMIN. (Mar 20, http://www.fda.gov/AboutFDA/Transparency/Basics/ucm325201.htm [http://perma.cc/B4ND-C23L].

43. 5 U.S.C. $\$ 553($ e) (2012 \& Supp. III 2015).

44. See sources cited supra note 11 .

45. 21 C.F.R. $\$ 10.30$ (2016). A variation on the standard citizen petition also exists, known as a "petition for stay of agency action." These petitions request that the FDA delay enforcement or the effective date of an administrative action. Id. $\$ 10.35$. They function and are governed similarly to citizen petitions, so we have grouped them together for the purposes of this 
must state all factual and legal grounds for the petition, provide all relevant information (including that which may be unfavorable), and add an environmental or economic impact section if necessary. ${ }^{46}$ The agency must make a final grant or denial of the petition. ${ }^{47}$

On its face, the citizen petition process should be a useful method for ensuring that the public can communicate its concerns to a key regulatory agency. A mechanism designed for concerned citizens and scientists to raise concerns about drugs, food, and FDA regulations, however, has seemingly turned into a playground for pharmaceutical companies to challenge drug applications, especially those related to pending generic applications. In many cases, the "concerned citizen" behind a petition is actually a large pharmaceutical company, seeking to stop or delay approval of a generic drug through a variety of different arguments. These include direct attacks against the generic's application and its bioequivalence or clinical data; appeals to safety; calls to preserve or add new exclusivities for the brand-name drug; and more. Some petitions raise important or necessary issues; many others, however, seem frivolous or questionable.

\section{A. Troubling Behavior in the Citizen Petition Process}

As an example of a troubling citizen petition we uncovered, consider the petition filed in 2007 by Mutual Pharmaceuticals, a company the FDA had already approved to sell a generic version of the blood pressure medicine felodipine. ${ }^{48}$ The petition sought to delay other generic companies from gaining approval. Specifically, the petition requested that the FDA not approve any new generic applications while it decided whether warnings should be added to the current drug labels regarding whether products containing certain forms of orange juice might affect absorption of the drug. ${ }^{49}$ The petition further suggested that all new generic drug approvals should be delayed until the FDA asked the original drug maker to

Article, a categorization that the FDA has used as well. U.S. Food \&. DRUG ADMIN., ANNUAL Report on Delays in Approvals of Applications Related to Citizen Petitions and Petitions for Stay of Agency Action For Fiscal Year 2008 (2009), http://www.fda.gov/downloads

/AboutFDA/CentersOffices/OfficeofMedicalProductsandTobacco/CDER/ReportsBudgets /UCM369793.pdf [http://perma.cc/76VK-ZRR3] ("Both citizen petitions and petitions for stay of agency action will be collectively referred to as 'petitions' throughout this Report.").

46. 21 C.F.R. $\$ 10.30$; see also Carrier \& Wander, supra note 10, at 260.

47. 21 C.F.R. $\S 10.30(e)(2)$. The Agency can also dismiss the petition if changes since the date of submission have rendered the petition moot. See id.

48. See Letter from Janet Woodcock, Dir. Ctr. for Drug Evaluation \& Research, U.S. Food \& Drug Admin., to Robert Dettery, Vice President, Regulatory Affairs, Mut. Pharm. Co. (Apr. 17, 2008), https://www.regulations.gov/document?D=FDA-2007-P-0123-0009 [http://perma.cc /D53D-8GQX] [hereinafter Response to Citizen Petitions]. Felodipine is also branded as Plendil.

49. Letter from Robert Dettery, Vice President, Mut. Pharm. Co., to Div. of Dockets Mgmt., U.S. Food \& Drug Admin. 1 (Nov. 29, 2007), https://www.regulations.gov/document ?D=FDA-2007-P-0123-0002 [http://perma.cc/MNP9-7WDE]. 
specify which form of orange juice was used in its studies. ${ }^{50}$ Of course, as a currently approved seller of generic felodipine, the company writing the citizen petition would be free to continue selling the existing labels based on existing study information.

Mutual Pharmaceuticals explained that its citizen petition was motivated by a study showing different effects of Seville orange juice versus "regular" orange juice on metabolism. ${ }^{51}$ Seville oranges are a smaller, more bitter orange often used for marmalade and liqueurs. ${ }^{52}$ The FDA, however, was unimpressed. ${ }^{53}$ In its response to the petition, the Agency stated, "we do not believe that the results of the Malhotra study present a serious safety concern. ${ }^{\text {" }}$ In fact, the FDA seemed to have a clear disdain for the claims made in the petition:

$[Y]$ ou hypothesize that there may be clinical consequences associated with the coadminstration of felodipine and components of Seville orange juice consumed in this form. You have offered no data to support this hypothesis. In fact, we searched the Adverse Event Reporting System (AERS) database and found no reported interactions between Seville or bitter orange products and any drug product. $^{55}$

A footnote hinted at the FDA's skepticism of Mutual's motives for filing the petition, questioning the truthfulness of Mutual's affirmations: "You have certified that you first became aware of the information upon which you have based Petition 1 (i.e., the Malhotra study) on November 5, 2007. We note, however, the Malhotra study was published in 2001 and predates approval of Mutual's [generic application]." 56

Unsurprisingly, Mutual was the first company to receive approval to sell generic felodipine, receiving approval from the FDA in 2004. Mylan, a competing generic drug company, filed the next generic application in the first quarter of 2007, just months before Mutual filed its citizen petition. ${ }^{57}$ The FDA denied the citizen petition the following year, on April 17, 2008-the same day that Mylan's generic application was approved. ${ }^{58}$ The timing indicates that Mutual's "orange juice petition" was one of the last barriers to final approval. Thus, a last-minute, baseless

50. See id.

51. See id. at 2.

52. See id. at 6.

53. See Response to Citizen Petitions, supra note 48 , at 2.

54. Id. at 4. The FDA did grant Mutual's request that a portion of the brand-name Plendil labeling stating that "[o]range juice does not appear to modify the kinetics of Plendil" be qualified to not imply that orange juice has no effects on the kinetics of Plendil, even if the minimal effect does not appear to affect the safety or efficacy of the drug.

55. Id.

56. Id. at 3 n.3.

57. See Feldman et al., Database, supra note $\S$, ANDA No. 78855.

58. See Response to Citizen Petitions, supra note 48, at 1; Drugs@FDA: FDA Approved Drug Products-Products on ANDA 078855, U.S. Food \& DRUG AdMIN. (Apr. 5, 2017), http:// www.accessdata.fda.gov/scripts/cder/daf/index.cfm?event=overview.process\&ApplNo=078855 [http://perma.cc/6KC5-9B8V]. 
petition about types of orange juice cost consumers untold millions by delaying the approval of a second generic for felodipine. ${ }^{59}$

This example of felodipine fits the rumors swirling about the current modus operandi for citizen petitions-pharmaceutical companies make a facially interesting, scientific-sounding claim (for example, Seville orange juice actually does increase absorption and peak drug concentration) timed to the months right before generic application approval, and the claims are eventually denied by the FDA. Despite the eventual denial, the delays cost consumers untold sums and waste governmental resources. ${ }^{60}$

\section{B. Changes to the FDA Citizen Petition Process}

After years of hearings and debate on numerous FDA regulatory issues, Congress passed the Food and Drug Administration Amendments Act (FDAAA) in 2007. The Act included the largest reform of the citizen petition process in the program's thirty-year history. ${ }^{61}$ These changes attempted to address concerns with citizen petitioning at the FDA, ranging from growing petition backlogs to signs that the process was being used inappropriately to delay entry of generic drugs. The Amendments aimed to curb attempts to both block and delay the entry of generics. ${ }^{62}$

Specifically, the 2007 Amendments added subsection "(q)" to section 355 of U.S. Code Title 21, where most of the legislation relating to generic applications already resided. This new provision generally is called "505(q)" in academic and regulatory discussions, and the petitions that fall under it are called "505(q) petitions."

Section 505(q) applies a new set of regulations to all citizen petitions that ask the FDA to take action related to a pending generic application. ${ }^{63}$ Most notably,

59. For example, sales of Plendil were $\$ 251$ million in 2007 , even with a generic already on the market. See Press Release, Mylan Pharm. Inc., Mylan Announces Final FDA Approval for Felodipine Extended-Release Tablets, USP (Apr. 21, 2008), http://newsroom.mylan.com/press -releases?item $=122579$ [http://perma.cc/5BHU-99HS].

60. See, e.g., Carrier \& Wander, supra note 10, at 252, 283-85 (detailing the saga of a citizen petition that delayed generic entry of the depression drug Wellbutrin XL for 133 days, costing consumers $\$ 600$ million).

61. FDA Amendments Act of 2007, Pub. L. No. 110-85, 121 Stat. 823 (2007) (codified as amended in scattered sections of 21 U.S.C.).

62. See Carrier \& Wander, supra note 10, at 263 (quoting 153 Cong. REC. 25,047 (2007)) (discussing testimony of Senator Edward Kennedy that " $[\mathrm{t}]$ he citizen petition provision is designed to address attempts to derail generic drug approvals. Those attempts, when successful, hurt consumers and the public health").

63. Section 505(q) covers citizen petitions related to two categories of FDA approval applications. These are abbreviated new drug applications (ANDAs) and other forms of applications that rely on investigations not performed by or for the applicant. The latter form is referred to as a 505(b)(2) application. See CTR. FOR DRUG EVALUATION \& RESEARCH, U.S. FoOD \& DRUg ADMin., GUIDANCE FOR INDUSTRY: APPLICATIONS COVEREd BY SECTION 505(b)(2) (Oct. 1999), http://www.fda.gov/downloads/Drugs/. . .Guidances/ucm079345.pdf [http://perma.cc 
the section requires that the FDA respond to all such petitions within 180 days. $^{64}$ In 2012, this deadline was further shortened to 150 days through the Food and Drug Administration Safety and Innovation Act (FDASIA). ${ }^{65}$ Approval of a generic application cannot be delayed because of a citizen petition beyond the 180-day (and later 150-day) review period, unless it is determined that a delay is necessary for public health reasons. ${ }^{66}$

Most importantly, §505(q) contains provisions intended to deter those who would file citizen petitions to delay generic competition. If a citizen petition relating to a generic application falls under $\S 505(\mathrm{q})$, the person filing the petition must certify that the petition is not frivolous, all information favorable and unfavorable has been provided, and the petitioner did not intentionally delay filing the petition. The citizen petition also must provide the date when the filer first became aware of the concern and the names of those who are funding the petition. ${ }^{67}$

Finally, § 505(q) grants the FDA the power to summarily deny any petition it believes was filed with the "primary purpose" of delaying generic approval if the petition also does not "on its face raise valid scientific or regulatory issues."68 Together, the provisions of $\S 505(\mathrm{q})$ were meant to end the abuse of citizen petitions by pharmaceutical companies.

The major changes to the citizen petition process beginning in 2007 serve as a natural break point in our data, allowing us to observe any effects of the legislation along with trends across time. In addition, some of the data reports mandated by the 2007 Amendments provide interesting information for our exploration. ${ }^{69}$

\section{METHOdOLOGY}

\section{A. Overview}

As described above, anecdotes have swirled for years suggesting that drug companies abuse the citizen petition process to keep generics off the market. ${ }^{70} \mathrm{We}$

/EA7F-L7B4] [hereinafter 505(b)(2) GUIDANCE].

64. 21 U.S.C. $\$ 355(q)(1)(f)$ (2012 \& Supp. III 2015).

65. Food and Drug Administration Safety and Innovation Act, Pub. L. No. 112-144, 126 Stat. 993 (2012) (codified as amended in scattered sections of 21 U.S.C.). The FDASIA also extended the stipulations of $\S 505(\mathrm{q})$ to biosimilar applications, which are beyond the scope of this paper.

66. 21 U.S.C. $\$ 355(q)(1)$ (2012 \& Supp. III 2015).

67. $I d$.

68. Id.

69. See infra text accompanying notes 127-139.

70. See, e.g., Feldman \& Frondorf, supra note 3; Ameet Sarpatwari, Jerry Avorn \& Aaron S. Kesselheim, Using a Drug-Safety Tool to Prevent Competition, 370 New EnG. J. Med. 1476, 1477 (2014) (citing Letter from Daniel E. Troy \& Gary L. Veron, Attorneys for Celgene Corp., to Div. of Dockets Mgmt., U.S. Food \& Drug Admin. (Sept. 20, 2007), https://www.regulations.gov /document?D=FDA-2007-P-0113-0002 [http://perma.cc/CHN4-H5XW]). Most importantly, Carrier and Wander, who documented a rise in citizen petitions in general, suggested that the 
set out to take a quantitative look. Specifically, our goal was to empirically explore whether pharmaceutical companies systematically use the citizen petition process to delay entry of generic drugs.

To approach the question, we sought to analyze the timing of when citizen petitions are filed during the generic drug approval process and the frequency with which petitions that have the potential to delay are filed. We hypothesized that such petitions would be filed towards the end of the approval process to put up one more roadblock in the path of successful approval of a generic drug.

Assembling the necessary information from the FDA's publicly available files was tremendously difficult. Although the FDA publishes a large amount of information on its public website, and more in hard copy through its Orange Book, ${ }^{71}$ much important information is absent. The necessary information often must be pieced together or estimated; in some cases, it simply cannot be located. For example, as will be described in more detail below, the FDA does not always publicly reveal the dates when generic applications are filed. We tracked down many of those dates by reading PDFs of various letters in the files of approved applications. For many others, however, we had to develop a method of identifying the likely quarter in which an application was filed by working from the FDA's file numbering systems.

The FDA citizen petition files also do not always link to or indicate which specific generic application the petition relates to-information that is important for tracking the timing of citizen petitions in relation to the application process for a particular generic drug. Moreover, prior to 2007, the FDA citizen petition files did not explicitly denote when a citizen petition targeted a generic application.

Despite these challenges, we set out to assemble a data set of citizen petitions that had the potential to delay generic applications, along with the relevant generic application and timing data. All of this information had to be assembled by piecing together information from the citizen petition letters and the various generic application files.

Through this approach, we assembled relevant data sets including 1) citizen petitions filed between 2000 and 2012 that had the potential to delay generic applications, along with their filing dates; 2) generic applications approved between the beginning of 2006 and the end of 2015; and, 3) the quarters in which the generic applications were filed and the specific dates on which they were approved. These data sets allowed us to analyze the timing of when citizen petitions are filed during the generic drug approval process and the frequency with which petitions that have the potential to delay are filed. In simplified form, the process can be summarized as follows:

rise might be a sign of delay behavior. See Carrier \& Wander, supra note 10, at 269-70, 283-86 (documenting empirically a rise in citizen petitions and detailing two anecdotal examples of petitions that resulted in delay, one related to the depression drug Wellbutrin and one related to the insomnia drug Ambien).

71. See supra text accompanying note 30 (describing the Orange Book). 
1) We compiled all FDA citizen petitions and related documents filed between 2000 to 2012.

2) We identified citizen petitions related to pharmaceuticals, with a particular focus on generic drugs.

3) We read each remaining citizen petition and determined which of these petitions were related to generic drugs or had the power to delay generic approval, regardless of the merits or circumstances of the petition.

4) We constructed a data set of all generic applications approved between 2006 and 2015, recording the approval date for each application.

5) We compiled filing dates for the generic applications, pulling them when available from PDFs of letters within the FDA's databases. When filing information was not publicly available, we were able to estimate a filing date down to the quarter-year for most drugs.

6) We matched each citizen petition with the generic application most relevant to the requests made in the petition.

7) Using these citizen petition-generic application pairs, we constructed metrics with the goal of isolating the timing of petitions during the generic drug approval process.

The subsections below describe the process in detail. As will be evident, collecting and assembling the data required extensive effort. The amount of effort required to extract the information from public sources, along with our commitment to open and ethical academic data, ${ }^{72}$ prompted us to make the data sets fully available to the public. ${ }^{73}$ We hope other academics will be able to use the data for future research.

\section{B. Methodology Details}

\section{Compiling All Citizen Petitions Filed Since 2000}

To begin our analysis, we compiled all documents related to citizen petitions that were filed with the FDA between the beginning of 2000 and the end of 2012 . We limited our data set to citizen petitions filed prior to 2013 because test analyses indicated that citizen petitions filed after 2013 frequently related to drugs that had not yet been approved. Without final approval files, one cannot find much of the information necessary for analysis. One also cannot reach timing conclusions about events within the approval process, given that the process is still underway.

The citizen petition documents were obtained using two sources. The first is an application program interface made available by Regulations.gov, a website provided by the federal government to serve as a searchable repository for

72. See Feldman et al., Open Letter, supra note $\S$.

73. See Feldman et al., Database, supra note $\$$. 
regulatory documents. The interface allows data to be queried and stored in formats easily accessible to data analysis languages. For the period from 2000 to 2012, we obtained 19,520 documents. Multiple documents, however, can correspond to a single citizen petition docket number. For example, supplemental data, support letters, and the FDA's actual response are different types of documents that may be listed separately but correspond to a single citizen petition. The 19,520 documents are linked to a total of 1,790 citizen petitions filed between 2000 and 2012 and archived online.

One should note, however, that the FDA's database on Regulations.gov may be incomplete. In addition, if the FDA's database has inconsistent labeling, the search may not have located every document. We are aware of at least a few citizen petitions that did not appear in our search of Regulations.gov because the FDA did not digitally categorize them as citizen petitions, but which we later added into our data set.

The second source is the FDA Law Blog's Citizen Petition Tracker, which keeps a record of citizen petitions that are related to generic drug applications. ${ }^{74}$ The Citizen Petition Tracker is a privately assembled data set available to the public. This data set, however, only reaches back to October 2007. When using data from FDA Law Blog, we hand-checked each of the blog's inclusions and sampled the blog's exclusions for each year, testing them against our own sorting of the information available from the FDA. We found no errors in the FDA Law Blog's data, and we believe it identifies a small number of citizen petitions that Regulations.gov fails to label as citizen petitions.

\section{Identifying Citizen Petitions that Could Delay Generic Competition}

With the full data set of citizen petitions in hand, we turned to identifying citizen petitions with the power to delay pending or forthcoming generic applications. This process involved two steps for removing non-relevant petitions: 1) removing petitions whose titles or categories indicated on their face that they were unrelated to delay of generic competition; and 2) removing petitions by viewing the content of the petition and related documents in full.

\section{a. Removing Citizen Petitions Unrelated on Their Face}

Our first step in eliminating citizen petitions unrelated to our inquiry was to remove petitions regarding other areas of FDA oversight. These included citizen petitions related to food (e.g. "Revise The Labeling Requirements for Eggs Sold In the United States"), medical devices (e.g. "Reclassification for Mobile Bearing Knees from Class III and Class II"), tobacco (e.g. "Reclassify Nicotine Vaporizers (E-

74. FDA LAW BLOG, http://www.fdalawblog.net [http://perma.cc/BUL6-PB57] (follow "FDA Citizen Petition Tracker" hyperlink). Once again, a similar method was used for verification by Carrier and Wander in their empirical look at citizen petitions. See Carrier \& Wander, supra note 10, at 118. 
cigarettes) from 'Drug-Device Combination' to 'Tobacco Product”), and dietary supplements (e.g. "Treat Weight Loss Claims for Dietary Supplements as Disease Claims"). After filtering out all of the above categories of petitions, the initial 1,790 petitions from $2000-2012$ were narrowed to 1,158 petitions. Thus, $65 \%$ of all citizen petitions filed at the FDA during the period from 2000 to 2012 were in some way related to pharmaceuticals.

Next, we removed drug-related petitions whose docket titles indicated that they were most likely unrelated to the possible obstruction of generic drug competition under consideration in our study. Thus, petitions related to biologic drugs were excluded. Biologic drugs are complex medications-such as antibodies, hormones, and proteins-that are derived from cells. Unlike the small-molecule drugs with which most people are widely familiar-such as aspirin-biologics and their generic "biosimilars" undergo a separate approval process, governed by a regulatory structure other than Hatch-Waxman. ${ }^{75}$ The biosimilar approval process differs substantially from Hatch-Waxman and is still in its infancy. In fact, the FDA approved the first biosimilar in March 2015, well beyond the 2000-2012 period of our study. ${ }^{76}$ Thus, analyses of potential delay tactics in the biosimilars regulatory pipeline are better suited for a different paper.

Petitions related to the approval of new animal drugs or generic animal drugs were also removed, given that they exist in a different class than standard smallmolecule medications.

We further chose to eliminate citizen petitions filed by third-party advocacy groups, rather than competitors, because we were looking for efforts by potential competitors to derail competition. An example of such a third-party petition is "Add a Black Box Warning About the Increased Risks of Heart Attacks and Other Cardiovascular Dangers to the Product Labels of all Testosterone-Containing Drugs Presently on the Market in the U.S.," filed by "Public Citizen," an advocacy group and think tank. ${ }^{77}$

One cannot eliminate the possibility that third-party groups such as these might collude with a pharmaceutical company or be unwittingly roped into behavior that has the happy coincidence of advancing an anticompetitive goal. Elements of the pharmaceutical industry have indeed taken heat in recent years for efforts to influence and finance academics and third-party groups. ${ }^{78}$ Given the

75. See Biologics Price Competition and Innovation Act of 2009, Pub. L. No. 111-148, 124 Stat. 119 (2010) (codified as amended at 42 U.S.C. \$262).

76. See Press Release, U.S. Food \& Drug Admin. FDA Approves First Biosimilar Product, Zarxio (Mar. 6, 2015), http://www.fda.gov/newsevents/newsroom/pressannouncements /ucm436648.htm [http://perma.cc/D9GN-9UUE].

77. Letter from Sidney Wolfe \& Michael Carome, Pub. Citizen's Health Research Group, to Margaret A. Hamburg, Commissioner, U.S. Food \& Drug Admin. 1 (Feb. 25, 2014), https://www.regulations.gov/document?D=FDA-2014-P-0258-0001 [http://perma.cc/LHM9 -T88Q].

78. See Feldman et al., Open Letter, supra note $\$$, at 341-43 (describing conflict of interest examples in life science research). 
source of these petitions, however, and the fact that this set of petitions rarely singled out specific generics, we chose not to include safety-related petitions filed by third parties in our analysis of timing relationships.

We also removed two defined categories of drug petitions most often filed by prospective generics seeking a route to the market-petitions that promote competition rather than seeking to restrict it. The first category is "ANDA suitability" petitions. A suitability petition is a request from a potential generic manufacturer to file an approval application for a drug that differs slightly from the original reference drug in characteristics such as route of administration, dosage form, and strength. ${ }^{79}$

The second category is "discontinuation petitions," which could also be described as "withdrawal determination petitions." When a drug is discontinued or removed from the market, the FDA must determine that the drug was not removed for reasons of safety or effectiveness before allowing it to be referenced in a generic application. Generic hopefuls can file a discontinuation petition asking the FDA to make this determination so a generic application can be filed. ${ }^{80}$ Given that both suitability and withdrawal petitions are, by definition, designed to allow additional generic entry, rather than to block or restrict entry, they were removed from our final database.

\section{b. Removing Citizen Petitions Unrelated Based on Their Content}

The second step in eliminating citizen petitions unrelated to our inquiry involved viewing each remaining petition docket in full. The number of documents available in each docket varies considerably, and our determinations were based on all available materials, including the petitions, interim FDA correspondence, and the FDA's available response. Our goal was to look at timing - not to make our own judgments on the legitimacy of any particular issue raised.

Once again, we sought to eliminate citizen petitions that had little or no relation to pending or approaching generic drug applications or were unrelated to the possibility of delay. Thus, we eliminated citizen petitions that would meet criteria used in the previous section for deletion, but for which that was not immediately apparent from the docket title, such as ANDA suitability, withdrawal, and third-party safety petitions.

In addition, citizen petitions related to new drug applications (NDAs) were taken out of the final database, given that they are generally unrelated to generic drug competition. One important exception is a specific category of new drug applications classified as “505(b)(2)s." Section 505(b)(2) applications fall somewhere

79. See Ctr. For Drug Evaluation \& Research, U.S. Food \& Drug Admin., Policy and Procedures: ANDA SuItABILITy Petitions (Aug. 21, 2013), http://www.fda.gov/downloads/AboutFDA/CentersOffices /OfficeofMedicalProductsandTobacco/CDER/ManualofPoliciesProcedures/UCM365676.pdf [http://perma.cc/CG3F-XZXZ].

80. 21 C.F.R. $\$ 314.161(\mathrm{a})$-(e) (2016). 
between pure applications for a new drug and applications for a generic drug. They are similar to filing an ANDA suitability petition in that both rely on existing data from existing drugs but involve drugs that differ from the existing ones in some aspect, such as formulation, dosage, treatment indication, or over-the-counter status. $^{81}$

As described above, we chose to eliminate ANDA suitability petitions from our data set on the theory that these represent an attempt by a generic company to enter the market and thereby broaden competition. In contrast, the 505(b)(2) citizen petitions that we kept within the data set represented attempts by other companies to block the entry of drugs-ones that are closely related to already-marketed pharmaceuticals and go through an approval process similar to approval for generic drugs. ${ }^{82}$

Similarly eliminated were those petitions that referred to drugs already on the market, often requesting that the FDA declare a drug "misbranded" or require labeling charges. Since these petitions refer to generic applications that have already been approved, they generally do not have the potential to delay generic approval, although they could potentially cause removal of the drug from the market. ${ }^{83}$

81. See Ctr. For Drug Evaluation \& Research, U.S. Food \& Drug Admin., 505(b)(2) GUIDANCE, supra note 63; supra text accompanying note 79 (describing ANDA suitability petitions). New drug applications (NDAs) fall under section 505(b)(1), and generic drug applications (ANDAs) generally fall under section 505(j). Suitability petitions and 505(b)(2)s are quite similar in the types of drugs that are eligible, but the differing processes (petition vs. application) appeal differently to generic companies depending on individual circumstances. Furthermore, the proposed differences in a drug implicated in a suitability petition cannot require new evidence that the new drug is safe and effective. An example of change that might not raise safety or effectiveness questions is when a generic proposes to a sell an intermediate dosage of an approved drug-say, a $300 \mathrm{mg}$ tablet when $200 \mathrm{mg}$ and $400 \mathrm{mg}$ tablets are already approved for the brand-name version of the drug. See Jennifer King, ANDA Sustainability Petition vs 505(b)(2), CAMARGO PHARM. SERVs.: 505(b)(2) BlOG (June 12, 2009), http://camargopharma.com /2009/06/anda-suitability-petition-vs-505b2 [http://perma.cc/8QKA-5G5J].

82. Notably, the $\S 505(\mathrm{q})$ requirements added in the 2007 Amendments apply to citizen petitions related to both ANDAs and $\$ 505$ (b)(2) applications. See CTR. FOR DRUG EvALUATION \& Research, U.S. Food \& Drug Admin., Citizen Petitions and Petitions for Stay of Action Subject to SECTION 505(q) OF THE FEDERAl FoOd, DrUG, AND COSMETIC ACT: GuidANCE FOR INDUSTRY 4-5 (1st rev. Nov. 2014), http://www.fda.gov/downloads/drugs /guidancecomplianceregulatoryinformation/guidances/ucm079353.pdf [hereinafter 505(q) GUIDANCE]; see also supra text accompanying notes 61-68 (describing the 2007 Amendments and $\S 505(\mathrm{q}))$.

83. This criterion is generally in line with current law and the guidance the FDA released interpreting the provisions of $\S 505$ (q) of the 2007 Amendments. First, $\S 505(\mathrm{q})(1)(\mathrm{A})$ specifically refers to pending applications, and the FDA has interpreted the Amendments to say that $\S 505(\mathrm{q})$ applies "only to petitions for which, at the time the petition is submitted, at least one ANDA, 505(b) (2) application, or biosimilar application related to the subject matter is pending." CTR. FOR DRUG EVALUATION \& RESEARCH, U.S. FOOD \& DRUG ADMIN., 505(q) GUIDANCE, supra note 82, at 6. It is important to note that our data set includes three citizen petitions filed on the same day or after the FDA approved the targeted generic application. These petition docket titles are FDA-2007-P-0349 (filed the same day as generic approval), FDA-2008-P-0117 (filed thirty days after generic approval), and FDA-2008-P-0616 (filed eight days after generic approval). We included FDA-2007-P-0349 because it was filed on the same day as generic approval, and without 
Finally, when the relation to generics was tenuous or unclear, we chose not to include the petition in our data set. For example, a number of petitions referred to a generic company's request to allow a drug to certify to multiple branded drugs, requests to list or delist patents from the Orange Book, and so on. While it is possible that some of these petitions may have been part of a generic delay scheme, our goal was to be as conservative as possible and err on the side of understating any potential results.

\section{c. The Final Citizen Petition Pool}

After removing the above categories, the remaining citizen petitions included only those with the potential to delay a pending or forthcoming generic competitor. The decision to include a citizen petition in the data set was based solely on the topic of the petition, and no attempt was made to judge the merits of the issues raised in the petition.

Many of the citizen petitions in the final pool specifically ask the FDA to stay or delay approval of a generic application. These citizen petitions frequently raise concerns about safety or incomplete bioequivalence or clinical testing, with bioequivalence testing a particularly prevalent topic. Many of these petitions ask the FDA to stay approval of a generic drug until the applicant presents evidence that the FDA already requires for approval of a generic drug. This type of petition essentially forces the FDA to make a redundant ruling that a certain type of testing is required, when in fact, that testing is already required.

These redundant petitions lead to a number of FDA rulings that grant a

the citizen petition filer knowing the exact date the FDA planned to approve the targeted drug, the petition could have had delay-related consequences. We included FDA-2008-P-0117 because it specifically asked for a stay of the FDA's approval, asserting its Paragraph IV first-filer certification and exclusivities. The petition also requests the FDA to stay approval on all other pending generic applications until the Federal Circuit renders a judgment on its Paragraph IV challenge; therefore, the petition attempts to delay generic approval and should be included in our dataset. See Letter from Bert. W. Rein, et al., Attorneys for Apotex, Inc., to Div. of Dockets Mgmt., U.S. Food \& Drug Admin. 1 (Feb. 13, 2008), https://www.regulations.gov/document ?D=FDA-2008-P-0117-0001 [http://perma.cc/LY32-WY2T]. We included FDA-2008-P-0616 because the citizen petition filer concedes that the FDA already approved a generic drug application, but requests that the FDA withdraw the approval and direct the applicant to refile as a 505(b)(2) application, rather than an Abbreviated New Drug Application (ANDA). See Letter from David L. Rosen, Attorney for Upsher-Smith Laboratories, Inc., to Dockets Mgmt. Branch, U.S. Food \& Drug Admin. 13 (Nov. 25, 2008), https://www.regulations.gov/document?D=FDA -2008-P-0616-0001 [http://perma.cc/7D8B-2667]). The difference between the two types of applications relates to the extent to which the generic drug differs from the brand-name drug. See supra note 63 \& infra text accompanying notes $85-86$. All three petitions described in this footnote were denied or declared moot, and thus, the date of approval of the generic application did not change. In calculating the time between when the citizen petition was filed and the relevant generic drug was approved for these three, we note that two of them occurred within a month after approval. Thus, we could have created an additional category for them representing negative time. To avoid skewing calculations and descriptive statistics, however, we chose to record their timing as the lowest positive category of within zero months. 
petition while not actually imposing any new requirements on the generic applicant. The result may be a petition that is granted in part and denied in part, with the granted portion no more than a formality that lacks practical significance. $^{84}$

Consider the FDA's response to a citizen petition that requested a stay of generic versions of Argatroban, a drug to prevent blood clotting. In its response, the FDA acknowledges that the actions granted in the petition are merely those already required under FDA policy, stating that " $[t]$ o the extent it is consistent with our current policies, we grant your request." 85

Other citizen petitions remaining in the pool ask that the FDA direct a generic applicant to re-file its application in a different form, changing it from an ANDA (the category for applications that reference an existing drug) to a 505(b)(2) (the category for applications that reference an existing drug but differ slightly in formulation, dosage, treatment indication, etc.) or demand that a generic applicant revise its application to reference additional patents. All of the requests would add additional burdens on a generic applicant to comply. Thus, they are best classified as petitions with the potential to delay generics.

For example, one petition uses a bioequivalence issue to suggest that

the Agency require the applicant(s) to withdraw the ANDA(s) and resubmit it as an application(s) under section 505(b) ... unless the ANDA applicant product is formulated with rsCT and is bio-identical in terms of biological impurities and an in vivo bioequivalency study has been completed and has met all bioequivalency criteria. 86

Such a request could represent a legitimate concern, or it could be a redundancy request, asking the FDA to require that the generic applicant do what all generic applicants must already do-prove bioequivalence. As noted above, we made no judgment about the legitimacy of the request in assembling the pool.

Another category of petitions has a less direct link to delaying generic approval. On occasion, pharmaceutical companies do not address specific generic applications or even the topic of generic approval in their citizen petition. Rather, the branded company requests that it receive additional exclusivities from the FDA or retain exclusivities that the company perceives to be under threat. ${ }^{87} \mathrm{We}$ have chosen to

84. See Carrier \& Wander, supra note 10, at 261, 266; see also id. at 261 (noting that the FDA's Director of the Office of Generic Drugs has made a similar observation, saying that "when petitions are granted, in whole or in part, it is often because the FDA already has the proposed scientific or legal standard in place or is already planning to take the action that the petition requests").

85. See Letter from Janet Woodcock, Dir., Ctr. for Drug Evaluation \& Research, U.S. Food \& Drug Admin., to Richard D. Kelly, Attorney for Mitsubishi Tanabe Pharma Corp. 8-9 (Aug. 19, 2009), https://www.regulations.gov/document?D=FDA-2009-P-0115-0006 [https:// perma.cc/5W6R-N2EC].

86. See, e.g., Letter from David L. Rosen, supra note 83, at 4.

87. For example, Petition FDA-2010-P-0188 asks the FDA to "confirm," among other related requests, that the "FDA will grant 180-day marketing exclusivity to Actavis' ANDA No. 77-302." Letter from Chad A. Landmon, Attorney for Actavis Elizabeth LLC, to Div. of 
categorize these petitions as potentially related to generic delay because gaining exclusivity pushes back the window for generic entry. Adding exclusivity is thus an attempt to extend the current state of the market-in which only a brand-name firm can compete, or only a brand-name firm and a first-filer can compete, for examplewhich, for existing sellers, is preferable to having a new generic enter the space. Interestingly, one petition filed by a pharmaceutical company openly identifies the relationship between its exclusivity request and delay of competitors: "[T]he requested stay would . . p prevent the approval of any ANDA or Section 505(b)(2) application referencing the Ziana ${ }^{\mathrm{TM}}$ NDA during the 3-year [sic] of market exclusivity that would be earned by the Ziana ${ }^{\mathrm{TM}}$ application if [the petitioner's other] citizen petition is granted."

The final pool of citizen petitions with the potential to delay introduction of generic drugs consisted of 249 citizen petitions filed between 2000 and 2012. This number represents a striking portion of the citizen petitions filed at the FDA during that period. In fact, $22 \%$ of citizen petitions related in some way to drugs ${ }^{89}$ and $14 \%$ of all citizen petitions filed on any topic at the FDA $^{90}$ in those years had the potential to delay the entry of generics.

\section{Timing of the Citizen Petitions Relative to Generic Applications}

For each of the 249 citizen petitions in the data set, we attempted to glean data about the timing relationship between the petition and the generic application implicated by the petition. Namely, we wanted to know how much time had passed between when the relevant generic application was filed and when the citizen petition was filed. We also wanted to track how much time had passed between when the citizen petition was filed and when the generic application was approved. Calculating these statistics required us to have information on when generic applications were filed and approved. Although one would expect such information to be readily available in the FDA's public information, that is not the case.

\section{a. Filing Dates for Generic Applications}

The FDA searchable database contains readily available information regarding approval dates for most generic drugs, to the specificity of month and day. Filing dates, however, are not so transparent. ${ }^{91}$ Assembling information on when a

Documents Mgmt., U.S. Food \& Drug Admin. 2 (Apr. 6, 2010), https://www.regulations.gov /document?D=FDA-2010-P-0188-0001 [http://perma.cc/T6YZ-9AKJ].

88. See Letter from Donald O. Beers \& Joshua M. Glasser, Attorneys for Medicis Pharm. Corp., to Div. of Dockets Mgmt., U.S. Food \& Drug Admin. 1 (Apr. 20, 2007), https://www .regulations.gov/document?D=FDA-2007-P-0295-0003 [http://perma.cc/F5VH-TEHV].

89. That is, 249 of 1,158 citizen petitions filed were related in some way to pharmaceuticals.

90. That is, 249 of 1,790 citizen petitions filed on any topic at the FDA.

91. Approval dates are, for the most part, readily available through the FDA's searchable 
generic application was filed required a combination of sleuthing through the various letters in the generic drug's public file and estimating based on information known from other drug applications. This process allowed us to determine with reasonable certainty the quarter in which an application was filed for $73 \%$ of the generic applications in our pool.

In particular, the way that docket numbers are assigned to generic applications makes it possible to estimate filing dates for those generic applications that do not have publicly available approval letters. To do this, however, we needed to look at the full set of all generic applications approved by the FDA between the beginning of 2006 and the end of 2015, which consists of 4,222 applications. ${ }^{92} 2006$ was the starting point of our range because we determined that very few drugs approved before this year were implicated in our set of citizen petitions filed between 2000 and 2012, and 2015 was the end point because it was the latest year for which generic approval data was available at the time we began collecting relevant information. 93

database of approved drugs, known as Drugs@FDA. See Drugs@FDA, supra note 58. For example, anyone can search Drugs@FDA for information on ANDA No. 90153 (a generic version of Ambien CR), and the page clearly denotes an approval date of March 25, 2013. But filing dates are not so transparent. The FDA does not have a standard data field in Drugs@FDA for ANDA filing date-clicking the "Approval Date(s) and History, Letters, Labels, Reviews" link on the page for ANDA No. 90153 results in no history, letters, or documents whatsoever other than a table displaying the approval date for the drug. This was the case for the majority of ANDAs we explored in the Drugs@FDA database. The only way to obtain filing dates is through rarely posted approval documents in a drug's "Approval Date(s) and History, Letters, Labels, Reviews" table. For example, the Approval Date(s) and History table for ANDA No. 202958 (a generic version of Keppra XR, an antiepileptic) stores PDFs of the final approval letter and approved label for the generic. In the first line of the approval letter from the FDA to generic manufacturer Apotex, it references ANDA letter dated March 31, 2011, indicating the generic filing date. See Letter from William P. Rickman, Ctr. for Drug Evaluation \& Research, U.S. Food \& Drug Admin. (Feb. 25, 2015), http://www.accessdata.fda.gov/drugsatfda_docs/appletter/2015/202958Orig1s000ltr.pdf [http://perma.cc/54ND-FS9F]. This-a brief mention in a PDF-only approval letter-appears to be the only way that filing dates have been made available to the public. We note that even that date may be slightly off. See, e.g., Letter from Sarah Cooleybeck \& James M. Flaherty, Jr., Attorneys for Fresenius Medical Care North America, to Div. of Dockets Mgmt., U.S. Food \& Drug Admin. 2 (Feb. 21, 2012), https://www.regulations.gov/\#!documentDetail;D=FDA-2012 -P-0184-0001 [http://perma.cc/H6HC-D6K2] (date stamp one day later than the date of the letter). Other sources agree that this is the only location for filing dates. In late March of 2016, however, FDA commentators began to notice that the FDA had started to remove all filing dates from approval letters, eliminating the only source of approval dates. See, e.g., Bob Pollock, Do You Notice Something Missing? What the Heck!, LaChman Consultants (Mar. 31, 2016), http://www.lachmanconsultants.com/2016/03/do-you-notice-something-missing-what-the -heck [http://perma.cc/FB93-6T6B]. This also means that our study range cannot be extended past 2015.

92. We also matched the generic applications to the reference drug using the FDA's Orange Book data. See supra text accompanying notes 30-32 (describing the Orange Book).

93. In rare exceptions, we discovered a citizen petition in our data set related to a generic application that was approved prior to 2006. We were able to use the same techniques described in this section to fill in filing dates for the relevant generic applications. Similarly, the FDA database of generic applications does not include approved 505(b)(2) applications. Thus, those applications were added as well, when necessary, for the 249 citizen petitions. 
In assembling the data set of generic applications, we included a wealth of information, such as the active ingredients, dosage form, generic company, and the name, number, and company for the original reference drug. We then sorted all of the generic applications by application number. This was a crucial step because generic application numbers are generally assigned sequentially within the different numerical series that exist. For example, generic applications for drugs initially approved before 1962 were assigned numbers in the 80,000s in order of filing date. The 80,000 s numbering scheme was replaced by sequential numbering starting in the 40,000s for generic applications referencing post-1962 FDA approvals.

For generic applications referencing drugs approved in the Hatch-Waxman era beginning in the 1980s, numbers were originally assigned in the 70,000s. That numbering scheme was eventually replaced by a 90,000 s numbering scheme in late 2007.94 The advent of the 90,000 s numbering scheme also retired the concurrent 40,000 series, so all generic applications from that point on were sequentially numbered in the 90,000 s. $^{95}$

When the FDA moved to a new IT platform in mid-2009, numbering changed once again. All drugs, including new drug applications and generic drug applications, were assigned six-digit numbers in the 200,000s. (Before this point, new drug applications were assigned five-digit numbers in the 20,000s, with even lower four- and five-digit numbers earlier in the FDA's history.) In general, the numbering of applications has remained sequential in order of filing date, but the 200,000 series is riddled with inconsistencies, in part because the FDA has allowed drug companies to reserve filing numbers before full submission of the necessary application materials.

The FDA's convoluted numbering history, despite its twists and turns, offers helpful clues about when a drug application was filed. A generic application filed in the 40,000s was filed after one numbered in the 80,000s; a generic application filed in the 70,000s came before generic applications in the 90,000s; a 200,000s generic application was filed later than any 90,000s generic applications; and so on.

On a more detailed level, sequential numbering within a given numerical series allowed us to estimate filing dates for most generic applications to the specificity of quarter-years, by using the filing dates the FDA occasionally provides in approval letters. ${ }^{96}$ Quarter-years were chosen as the time unit for estimating filing dates

94. Estimated switch time is based on our database.

95. Kurt R. Karst, FDA Denies Petition Seeking to Add Application Information to Drug Labels, FDA LAW BLOG (Jan. 12, 2012, 4:33 PM), http://www.fdalawblog.net/fda_law_blog _hyman_phelps/2012/01/fda-denies-petition-seeking-to-add-application-information-to-drug -labels.html [http://perma.cc/3AVW-3MFE]. To further complicate the numbering history, generic applications for antibiotics were previously assigned numbers in the 50,000s and 60,000s. These series were also retired when the 90,000s numbering scheme was introduced.

96. By quarter-year we mean the following: January-March is the first quarter of a year, April-June is the second quarter, July-September is the third quarter, and October-December is the fourth quarter. For example, generic application No. 77715 was filed on May 19, 2005 (the second quarter of 2005), and generic application No. 77743 was filed on June 15, 2005 (also in the second quarter). With those two bookends available, we know that all generic applications in 
because they represented the best trade-off between being able to estimate a fair majority of filing dates while also maintaining the level of granularity needed to examine citizen petition timing, where a few months can make a difference in delay. For example, the FDA must respond to citizen petitions filed after mid-2012 in 150 days-precisely one and two-thirds quarters. First-filer exclusivity lasts 180 daysprecisely two quarters. When an estimate could not be made properly-for example, if the two available dates bookending an empty generic application were in two separate quarters-no quarter is entered. Again, this was an effort to err on the side of caution in assembling the information.

This estimation process should be accurate in the vast majority of cases, but we do note that there may be occasional errors, particularly for generic applications numbered in the 200,000s. Fortunately, only four citizen petitions were matched to generic applications in the 200,000 series for which filing dates had to be estimated.

Of the 4,222 generic applications approved between 2006 and 2015, 980 had exact filing dates available in approval letters, representing 23\%. A further 2,108 filing dates were estimated using the process described above, representing 50\%. In all, the quarter in which a generic application was filed was found or estimated for 3,088 generic applications, a success rate of $73 \%$.

\section{b. Matching Citizen Petitions to Relevant Applications}

Having constructed the data set of filing and approval dates for generic applications, we then sought to match the data set of 249 citizen petitions with the generic applications implicated by these petitions. In other words, what generic application would be most directly impacted, and potentially delayed, by the filing of the citizen petition?

Occasionally, the "offending" generic application was explicitly named in the citizen petition. $^{97}$ In most cases, however, the object of the citizen petition's complaint was not so clear, perhaps because drug companies want to spread a wide net over all potential generic applications related to their existing drug. Similar to many citizen petitions, for example, Petition FDA-2009-P-0364 states, "Graceway respectfully requests that FDA refuse to approve any ANDA for a generic imiquimod cream product that seeks to rely on FDA's prior approval of Aldara, unless the application contains data from [bioequivalence studies, among

between, such as 77725, 77733, and 77741-all generic applications for which filing dates are not available-were almost certainly also filed in the second quarter of 2005. In our database, we marked these generic applications as having been filed in "2005-2," with "2" representing the second quarter. We also included a flag to denote which filing dates were estimates and which were precise dates provided by the FDA.

97. For example, Petition FDA-2012-P-0184 specifically asks that the FDA "refuse to accept Cypress ANDA No. 20-2820 for filing (or find ANDA No. 20-2820 not approvable if already accepted for filing)." See Letter from Sarah Cooleybeck \& James M. Flaherty, Jr., supra note 91 , at 2 . 
others]." 98

When a specific generic application was not identified, we turned to our generic application data set to find the first generic application filed that referenced the petitioner's drug. ${ }^{99}$ The first-filer is significant for a number of reasons-it opens the floodgates to generic competition, bringing an initial drop in price and market share and more substantial reductions as other generics enter later on. Thus, the first generic application is the most lucrative milestone for a brand-name company to delay or block.

Making this determination requires careful analysis, given that a drug's characteristics outside of the active ingredients, such as dosage or route of administration, often mattered in making the first-filer determination. Consider, for example, Petition FDA-2011-P-0702, filed on September 23, 2011. This citizen petition asks the FDA not to approve any generic applications for Doryx (doxycycline hydrate). The petition specifically refers, however, to generic applications "for a $150 \mathrm{mg}$ doxycycline hyclate delayed-release tablet product." 100 Thus, the generic application relevant to the petition is most likely application No. 91052, the first generic filing for a $150 \mathrm{mg}$ delayed-release tablet form of the drug.

Although we generally looked for the first-filed generic application as the appropriate reference point for a citizen petition, in a few instances, the first-filer could not have been the subject of the citizen petition. This occurred, for example, when a generic filed a petition seeking to prevent another generic from entering the market. A market with just two or three players is still a potentially lucrative one, so it is not surprising to see generics also engage in citizen petitioning to keep the number of generics down. In these cases, we attempted to identify the nextfiled generic application when possible. Similarly, when the first generic company to file an application was already on the market at the time of the citizen petition, meaning it could not be the subject of a petition trying to prevent approval or submission, we also chose a later application as most likely related.

One should also note that citizen petitions can be submitted before the first generic application is filed, a type of preemptive strike against any generic submission. For example, Petition FDA-2009-P-0042 requests that the FDA approve no applications for a generic version of Argatroban. ${ }^{101}$ The petition was filed on January 30, 2009, but we determined that the first generic application

98. Letter from James H. Lee, Chief Med. Officer, Graceway Pharm., LLC, to Comm'r of Food \& Drugs, Div. of Dockets Mgmt., U.S. Food \& Drug Admin. 2 (July 30, 2009), https://www .regulations.gov/document?D=FDA-2009-P-0364-0001 [http://perma.cc/7LU9-F8SG].

99. If multiple ANDAs were explicitly named in a petition, we identified the first-filed petition of those mentioned.

100. Letter from Izumi Hara, Senior Vice President \& Gen. Counsel, Warner Chilcott (U.S.), LLC, to Div. of Dockets Mgmt., U.S. Food \& Drug Admin. 1 (Sept. 23, 2011), https://www .regulations.gov/document?D=FDA-2011-P-0702-0001 [http://perma.cc/NYA4-F2Z2].

101. Letter from Richard D. Kelly, Attorney for Mitsubishi Tanabe Pharma Corp. to Dockets Mgmt. Branch, U.S. Food \& Drug Admin. 1 (Jan. 30, 2009), https://www .regulations.gov/document?D=FDA-2009-P-0042-0001 [http://perma.cc/8AKU-9WV8]. 
(No. 91665) was not filed until two quarters later. ${ }^{102}$ In those cases, the time from the filing of the generic application to the filing of the citizen petition was negative. Citizen petitions that could not be definitively linked to a generic application or for which appropriate timing data was not available were removed from our analysis.

At the conclusion of this process, 164 delay-related citizen petitions of the 249 originally identified were linked to a generic application that had data availableeither a filing date, an approval date, or both. ${ }^{103}$ This is a success rate of nearly twothirds, or $65.9 \%$, among the citizen petitions identified as having the potential to delay generic entry. Of those 164 petitions, 152 (or $61 \%$ of the total 249 petitions) were linked to generic applications with both the filing date and approval date. ${ }^{104}$ In sum, out of the 249 citizen petitions with the potential to delay generic entry, we were able to establish at least partial timelines for the generic applications with which they were most likely associated for nearly two-thirds, and full timelines for $61 \%$.

\section{c. Establishing Key Metrics}

Using our final data set of 164 citizen petitions paired with relevant generic applications with timing information, we were able to create the following metrics:

- The number of quarters between when the relevant generic application was filed and when the citizen petition was filed ("Quarters Since Generic Filing”).

- The number of months between when the citizen petition was filed and the final approval of the relevant generic application ("Months Before Approval").

- How long the generic application took to gain approval from start to finish (its “Total Approval Time” or "pendency”).

- At what point in the relevant generic application's pendency the citizen petition was filed (the "Percentage Into Pendency"). ${ }^{105}$

102. We note that it is possible, despite our efforts, that the generic application identified is not necessarily the first-filed generic application. If the actual first-filed generic application was never approved, it would not appear in the FDA's public records. We do not think this occurrence is particularly likely, but we note that the lack of availability of unapproved generic applications may cause our data to miss applications that suffered the most from delay tactics, such as those that had to be withdrawn or those that were never approved because of issues with generic delay.

103. In rare circumstances, a filing date was available but not an approval date. This occurred when a drug had only been tentatively approved but was still posted on the FDA's website with an attached letter noting the filing date.

104. There were a total of 157 delay-related citizen petitions with filing information (including those with only a filing date and those with both a filing and approval date) and 159 delay-related citizen petitions with approval information (including those with only an approval date and those with both a filing and approval date).

105. As an example, Petition FDA-2007-P-0418 was filed on November 9, 2007, the fourth quarter of 2007. We estimated that its relevant generic application, ANDA No. 78441, was filed in the third quarter of 2006. It was approved on May 14, 2009, the second quarter of 2009. 
We used quarters as the standard measurement basis for "Quarters Since Generic Filing," “Total Approval Time,” and "Percentage Into Pendency,” because those metrics required generic filing dates, many of which had to be estimated at the level of quarters. Meanwhile, we were able to use months rather than quarters for "Months Before Approval" because, unlike with generic filing information, exact dates to the specificity of month and day were available for both citizen petition filing and generic approval.

Examining these core metrics will reveal trends of how citizen petitions interact with the generic approval process.

\section{RESUlts}

\section{A. Overview}

As described in the opening section, the results of the study provide empirical evidence that the citizen petition process at the FDA has become a key avenue for strategic behavior by pharmaceutical companies to delay entry of generic competition. The following sections describe those results, but the most important findings are the following:

- The FDA's citizen petition pathway is one of the key pathways involved in the modern generation of generic drug delay, playing a role in various game-playing strategies.

- Citizen petitions from competitor companies-brand names and generics seeking to delay competitors-have essentially doubled since 2003.

- Citizen petitions with the potential to delay generic entry occupy a striking amount of the process in recent years. Out of all citizen petitions filed at the FDA between 2000 and 2012 (including those dealing with tobacco, food, dietary supplements, medical devices, etc.), nearly $15 \%$ had the potential to delay a generic drug application, climbing to $20 \%$ in some years.

- Many citizen petitions from competitor companies appear to be lastditch efforts to hold off generic competition. In fact, the most common grouping of petitions was those filed within six months of generic approval. This is particularly striking given that the overwhelming majority of citizen petitions are denied. ${ }^{106}$ In other

Between the third quarter of 2006 (generic application filing) and the fourth quarter of 2007 (citizen petition filing), five quarter-years had passed, so the value of "Quarters Since Generic Filing" for this citizen petition is "5." Eighteen months and five days passed between November 9, 2007 (citizen petition filing) and May 14, 2009 (generic approval), so "Months Before Approval" for this petition is "18." Its "Total Approval Time," from the third quarter of 2006 to the second quarter of 2009, is 11 quarter-years. The citizen petition came five quarters into the generic application's 11-quarter pendency, so the "Percentage Into Pendency" is approximately $45.5 \%$.

106. See Carrier \& Minniti, supra note 12 (finding that between 2011 and 2015, the FDA 
words, the results suggest that many competitor petitions are filed late in the game, as a last-ditch effort to hold off competition just a little longer, even though they are unlikely to be successful.

- Congressional reforms enacted in 2007 have not stemmed the tide of such delay-related petitions.

\section{B. Rise in Citizen Petitions with the Potential to Delay}

A few observations emerge from Table I below. First, it is notable just how many citizen petitions seem to have the potential to delay generic entry, with proportions above $20 \%$ in 2010 and nearing $20 \%$ in other years. That means one in five of all citizen petitions-not just those concerning pharmaceuticals-were related in some way to pending generic applications or brand-name exclusivity in those years.

Table I also adds more evidence for the hypothesis made earlier that petitions rose in popularity as a way to delay generics or raise issues about generics starting in 2003 and 2004. Not only did the number of citizen petitions rise noticeably after 2002, but the number of delay-related petitions also has sharply increased as a proportion of all petitions.

denied $92 \%$ of $\S 505(\mathrm{q})$ citizen petitions, the type most often employed to oppose generic entry); Carrier \& Wander, supra note 10 (finding that the FDA denied $81 \%$ of all citizen petitions filed by competitors against drug companies between 2001 and 2010). 
TABle I - All Delay-Related Petitions, By YeAR

\begin{tabular}{|c|c|c|}
\hline YeAR & $\begin{array}{c}\text { Number OF Delay-Related } \\
\text { Petitions }\end{array}$ & $\begin{array}{c}\text { Percentage OF YeARLY Total } \\
\text { Petitions }\end{array}$ \\
\hline 2000 & 2 & $2 / 47=4.3 \%$ \\
\hline 2001 & 4 & $4 / 63=6.3 \%$ \\
\hline 2002 & 5 & $5 / 106=4.7 \%$ \\
\hline 2003 & 12 & $12 / 120=10.0 \%$ \\
\hline 2004 & 26 & $26 / 178=14.6 \%$ \\
\hline 2005 & 15 & $15 / 148=10.1 \%$ \\
\hline 2006 & 24 & $24 / 184=13.0 \%$ \\
\hline 2007 & 25 & $25 / 160=15.6 \%$ \\
\hline 2008 & 23 & $23 / 166=13.9 \%$ \\
\hline 2009 & 32 & $32 / 171=18.7 \%$ \\
\hline 2010 & 31 & $31 / 149=20.8 \%$ \\
\hline 2011 & 22 & $22 / 157=14.0 \%$ \\
\hline 2012 & 28 & $28 / 141=19.9 \%$ \\
\hline TOTAL & 249 & $249 / 1,790=13.9 \%$ \\
\hline
\end{tabular}

\section{When Are Citizen Petitions Filed in Relation to Final Approval?}

We now turn to the results regarding the timing of when competitors file citizen petitions and the implications of that timing. The results described below suggest that many drug companies are filing citizen petitions as a last-ditch effort just months before generic approval. Moreover, many of these citizen petitions may be the last barrier standing in the way of final generic approval.

We reached these conclusions in the following manner. For 152 of the 164 citizen petitions in our data set, both a filing date and an approval date were available for the relevant generic applications, allowing us to calculate the average length of time a generic application takes from filing to approval. We will refer to this as the "total approval time." On average, the total approval time for generic applications in our data set was 16.5 quarters, or approximately a little over four years.

The histogram shown below in Figure I categorizes the generic applications based on the amount of time for which they were pending; the first bar, for example, corresponds to the nine generic applications that were pending for 1-4 quarters.

It is important to note that the generic applications that make up this calculation were those that had related citizen petitions. Thus, the information may not be generalizable to all generic applications. The limitation does, however, allow us to explore whether citizen petition reforms may have had an impact by reducing 
the total application time for a generic. In particular, despite the 180-day (and later 150-day) deadline on responding to citizen petitions, the average total application time for a generic was slightly longer for generics paired with petitions filed after the 2007 Amendments. In fact, the total application time for generic applications paired with delay-related citizen petitions was almost $10 \%$ longer after the 2007 Amendments. ${ }^{107}$

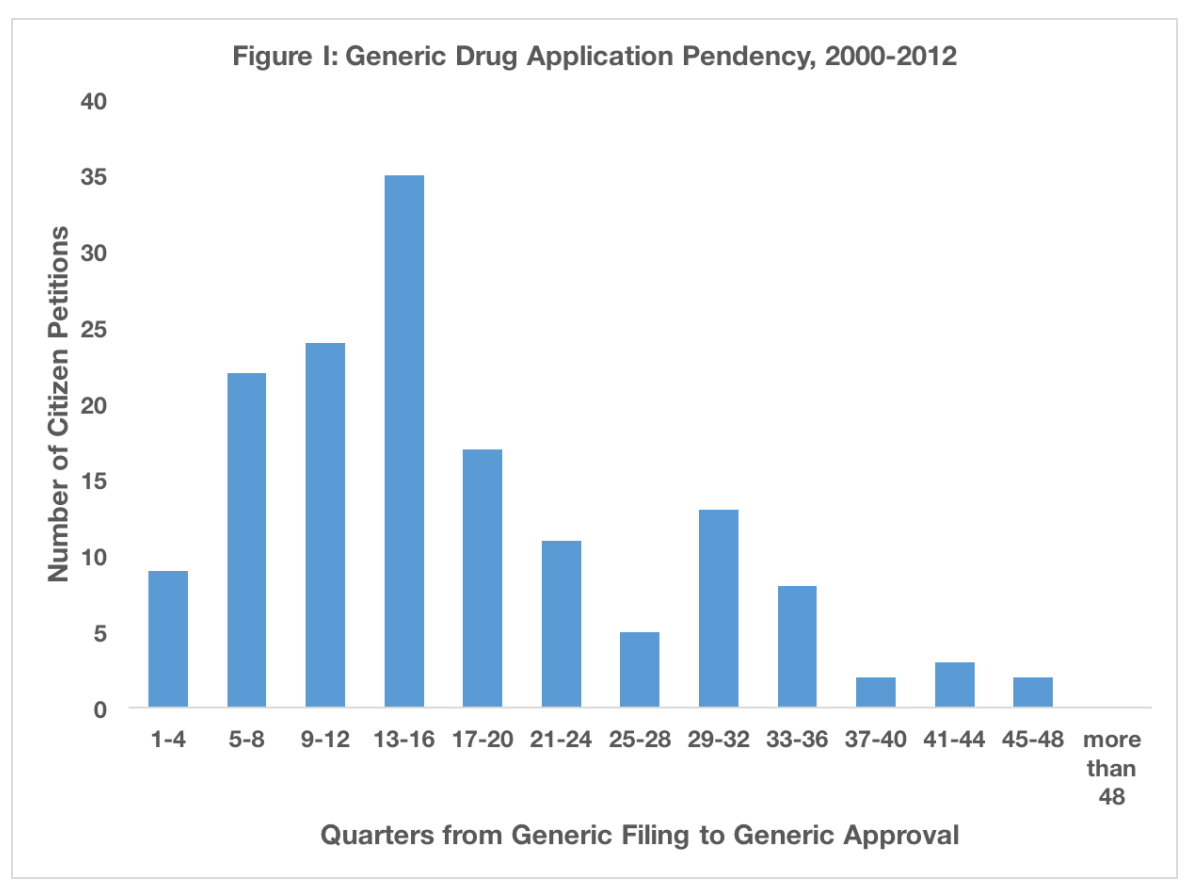

Next, we graphed the distribution of quarters that passed between filing of the relevant generic application and filing of the linked citizen petition, which is shown below in Figure II. We refer to this metric as "quarters since generic filing." The histogram displays the number of citizen petitions that fell into each category; for instance, the bar labeled " $0-2$ " indicates that the amount of time since generic filing was between zero quarters and two quarters for nineteen citizen petitions. This metric was available for 157 citizen petitions-the number of citizen petitions linked to generic applications with filing dates located or estimated.

A significant majority-over 75\%-of the 157 citizen petitions were filed within 0-14 quarters after the relevant generic application was filed. Almost 90\% were filed more than two quarters after the relevant generic application was filed, indicating that, in the large majority of cases, petitions are not fired off shortly after the announcement of a generic application.

107. Generic applications paired with citizen petitions prior to the 2007 Amendments had an average total application time of 15.76 quarters compared with 16.95 quarters after the 2007 Amendments. 




The most interesting and profound result, however, arose when we graphed the amount of time between when a citizen petition was filed and when the linked generic application was approved. We call this metric "months before approval." Our original hypothesis was that if citizen petitions are being used systematically to delay the approval of generics, citizen petitions might be deployed most effectively for that purpose near the end of a generic approval cycle. If filed earlier, a citizen petition would merely introduce a review process running parallel to the generic submission.

Figure III below shows the results of this timing inquiry. First, we graphed the distribution of how many months passed between when the citizen petition was filed and when the generic received approval. ${ }^{108}$

108. In Figures III, IV, and V, the "0-6" month and "6-12" month categories along the $\mathrm{x}$ axis are non-overlapping. The " $0-6$ " category covers all citizen petitions filed up to six months before generic approval. The "6-12" category covers all citizen petitions filed six months and any number of days (i.e., six months and one day through six months and thirty/thirty-one days) before generic approval. The same applies for the rest of the categories along the $\mathrm{x}$-axis. 


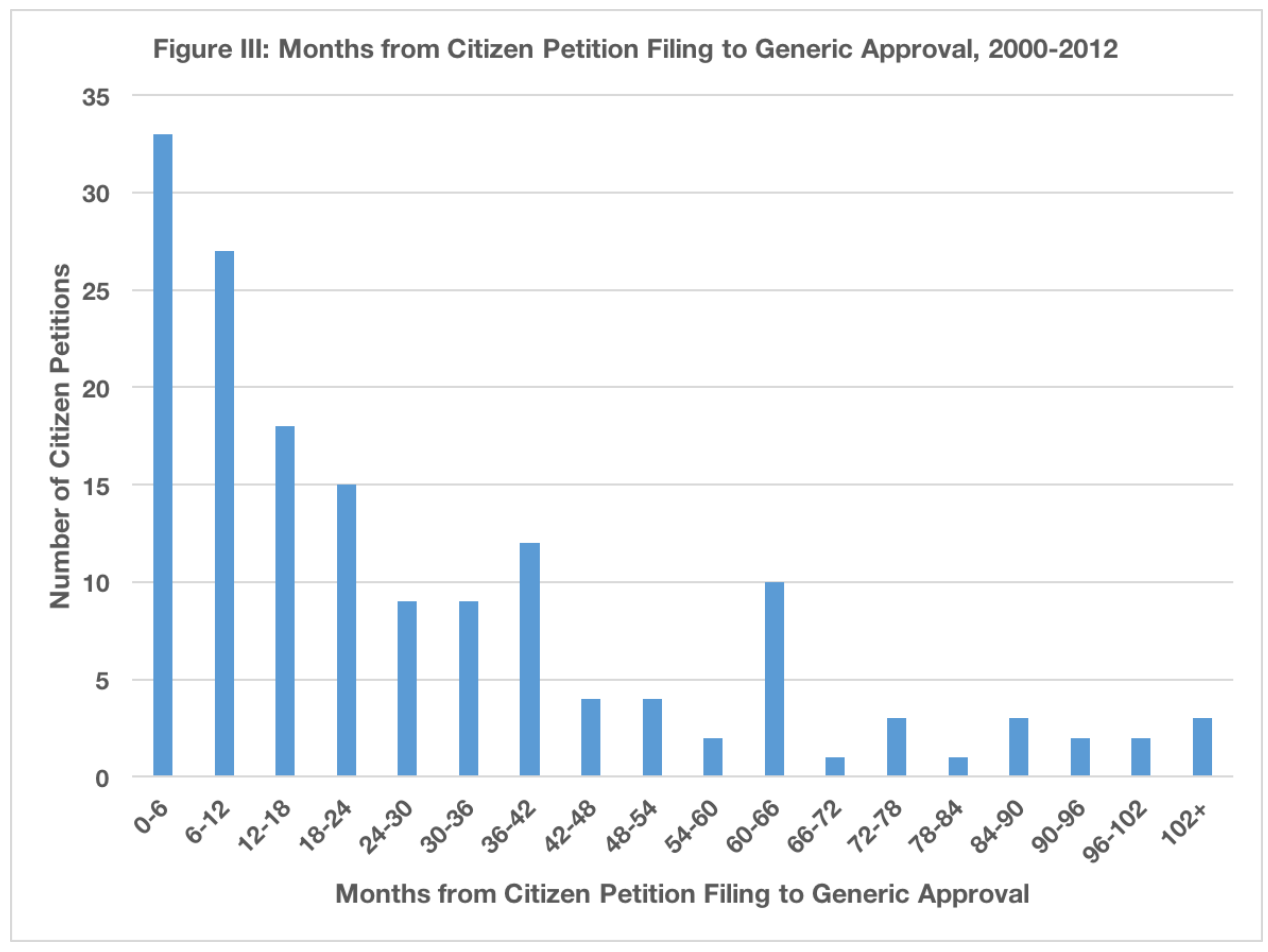

There is a clear trend in favor of citizen petitions filed shortly before the FDA approves a generic. Almost half were filed within a year and a half of generic approval, with roughly $40 \%$ filed a year or less before generic approval. ${ }^{109}$ In fact, the most common category was "0-6 months," with 33 petitions, or $21 \%$ of the total, ${ }^{110}$ filed with up to 6 months or less remaining before the FDA approved the generic. Considering that the average length of time from generic filing to approval is roughly four years, this category occurs most often during the final leg of the approval process.

In other words, the trend is towards an increasing number of petitions as one moves closer to the final approval date. Thus, the histogram shown in Figure III above suggests that delay-related citizen petitions are often filed in the final stages of generic approval, raising concerns at the last minute, rather than early or midway through the process. This pattern potentially extends the length of the generic approval process, thus delaying the market entry of generic competition.

109. To clarify, we noted above that we had 164 citizen petitions with at least partial time line information. Of these, we had generic approval dates for 158 and thus could measure the time between filing of the citizen petition and approval of the generic for those 158 . Of the 158 petitions, 78 petitions (49\%) were filed within 18 months of generic drug approval and 60 petitions (38\%) were filed within 12 months of generic drug approval.

110. The number of citizen petitions filed 6 months or less before generic drug approval was 33 out of a total of 158 petitions (21\%). 
Figure IV below looks specifically at the period before the 2007 Amendments. In this period, $41 \%$ of petitions were filed within a year and a half of generic approval. $^{111}$

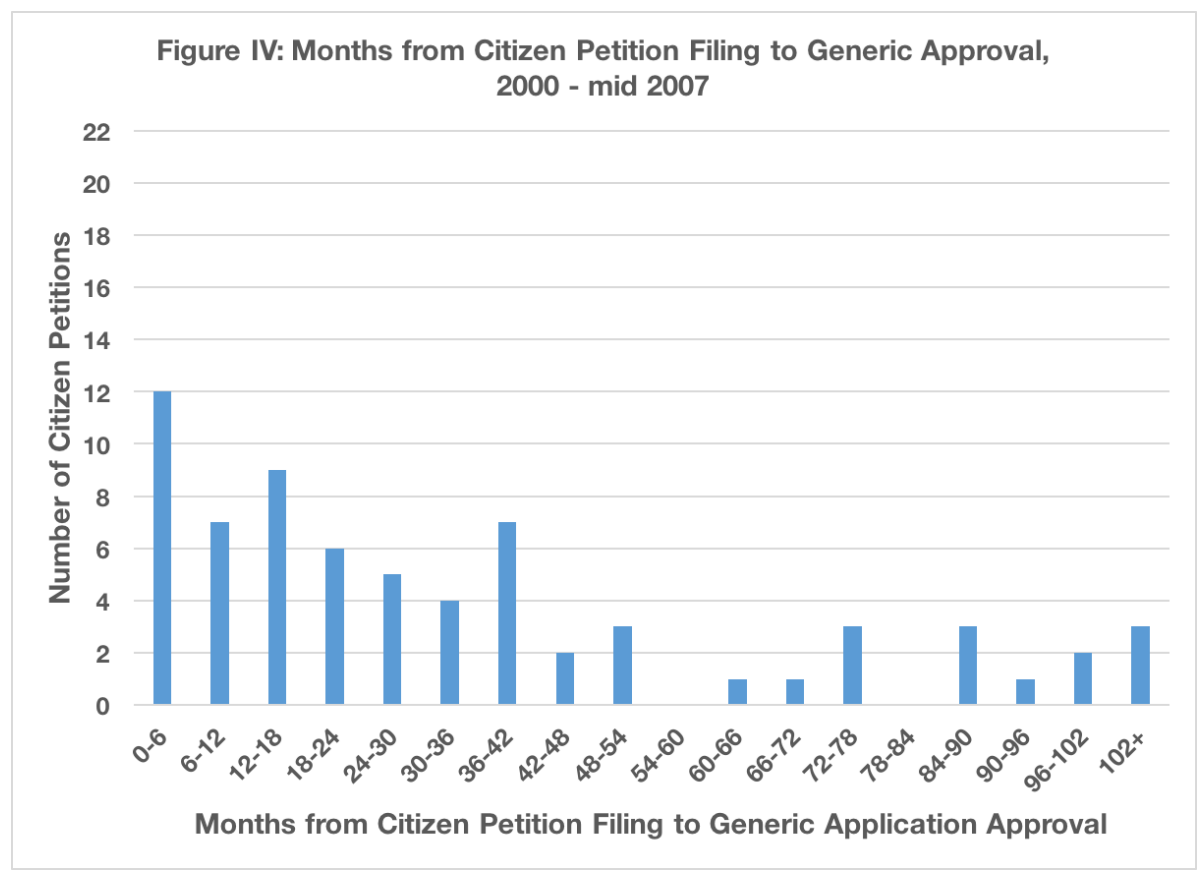

In the period after the 2007 Amendments, the trend is even more dramatic, as shown in Figure V below. Of the 89 petitions filed in the post-2007 Amendments period, $56 \%$ were filed within a year and a half of generic approval. ${ }^{112}$ In fact, a remarkable $46 \%$ of petitions (41 petitions) were filed within a year of generic approval. The "0-6 months" and "6-12 months" categories were by far the most popular, garnering $24 \%$ and $22 \%$ of the total, respectively. ${ }^{113}$

111. A total of 69 citizen petitions were filed in the period before the 2007 Amendments. Twenty-eight of them were filed within 18 months of generic drug approval (41\%).

112. In the post-2007 Amendments period, we measured a total of 89 citizen petitions relating to generic drug applications with approval dates available. Of those 89 petitions, 50 were filed within 18 months of generic drug approval (56\%).

113. In the post-2007 Amendments period, the number of citizen petitions filed within six months of generic approval was 21 out of a total of 89 petitions (24\%). The number of citizen petitions filed between 6 months and 12 months of generic approval was 20 out of a total of 89 petitions $(22 \%)$. Our findings are consistent with another study using a different methodology. In their examination of generic-related citizen petitions filed between 2011 and 2015, Carrier and Minniti found that $39 \%$ of drugs named in petitions were subject to a citizen petition within 6 months of a brand-name drug's "exclusionary date"-the date when a brand-name patent or FDA exclusivity would expire. Carrier \& Minniti, supra note 12, at 338, 339 tbl.8. Ninety-eight percent of these "late-filed" petitions were denied. Id. at 351, 339 tbl.8. Our choice of sample in this study 


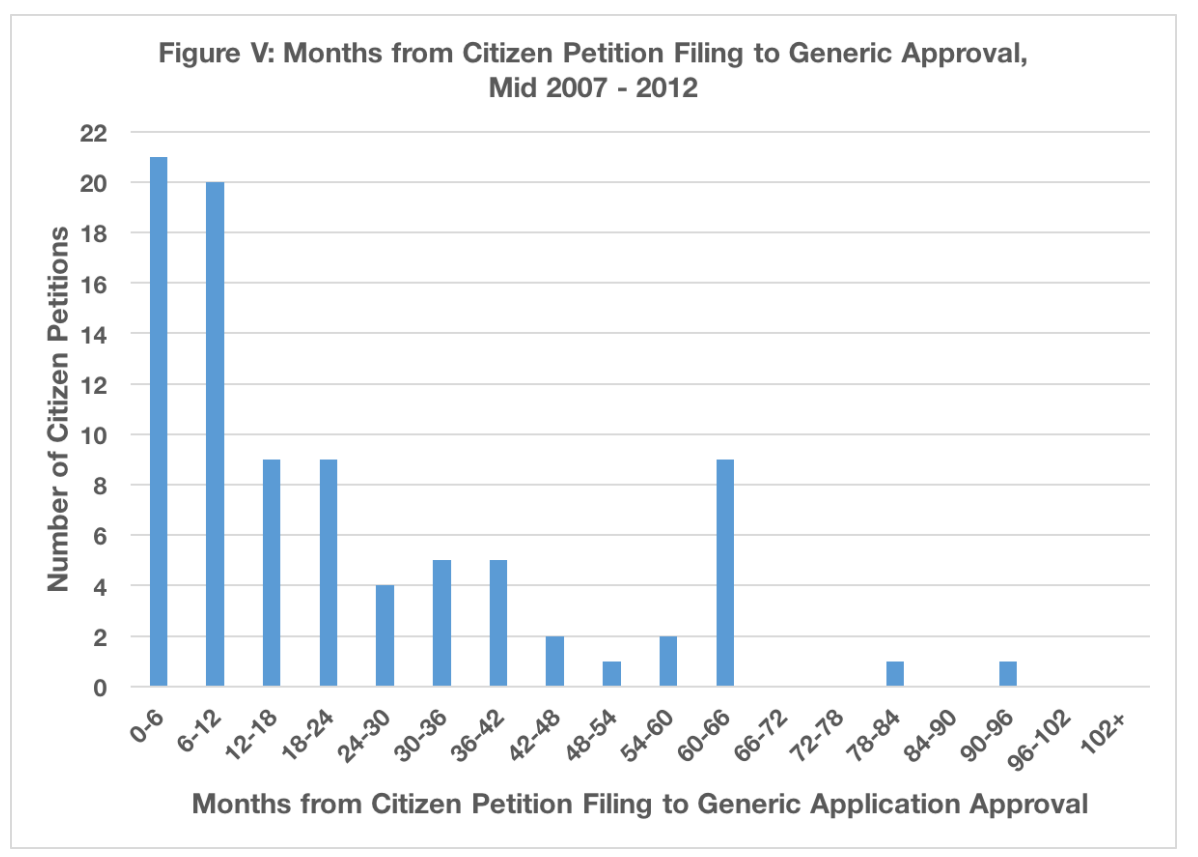

The biggest exogenous shift between the 2000 to mid-2007 histogram (Figure IV) and the mid-2007 to 2012 histogram (Figure V) is, of course, the enactment of the 2007 Amendments. Its most notable change-requiring that the FDA respond to citizen petitions within 180 days-may explain why the post-2007 graph (Figure V) paints such a dramatic picture of citizen petition timing.

Here is the observation: The FDA's 180-day time limit for responding to citizen petitions equates to six months, which aligns exactly with our smallest category of 0-6 months. From this perspective, one can see that for a remarkable percentage of citizen petitions filed after 2007, approval for the relevant generic is occurring right around the time when the FDA must respond to the citizen petition. Specifically, from the middle of 2007 to 2012, we see a plurality of citizen petitions filed within six months of final generic approval.

This has two implications: first, many drug companies are filing citizen petitions as a last-ditch effort just months before generic approval; and, second, many of these citizen petitions may be the last barrier in the way of final generic approval.

Put another way, when so many generic applications are approved within 6 months-the equivalent of 180 days-of when a citizen petition is filed, and the FDA had 180 days to respond to the citizen petition, the relationship does not seem

was slightly different-Carrier and Minniti focused only on petitions given a "505(q)" designation by the FDA. 
to be mere coincidence. This may also explain why the trend toward late citizen petitions is not as pronounced in the period before the 2007 Amendments: citizen petitions may have still been filed during the late stages of the FDA's consideration of generic applications, but since the FDA was not held to a specific deadline for responding to citizen petitions, lengthy petition reviews could have pushed back the horizon for final generic approval by more than six months. Delving deeper into this striking correlation between the FDA's deadline of 180 days and the plurality of citizen petitions filed within 180 days of generic approval would be an interesting avenue for future research.

\section{When Are Citizen Petitions Filed as a Percentage of the Total Application Time?}

We consider the results in the section above to be the most significant of the study, but we did discover an additional interesting finding-one that suggests pharmaceutical companies are not following the FDA's mandate that a citizen petition must be filed as soon as the concerning information comes to light. As described above, the 2007 Amendments are intended to encourage people to file citizen petitions as soon as they discover a problem. Filers are required to certify that the petition was not intentionally delayed and provide the date when the filer became aware of the concern. ${ }^{114}$ The following results suggest that is not the case for most of the citizen petitions in our data set.

In tracing timing issues in Figure II, we had focused on the time between when a generic application is filed and when the citizen petition is filed. Measuring the quarters between filing of the generic application and filing of a citizen petition does not necessarily provide a precise measure of how late in the process a citizen petition is filed, because even though the average approval time is around four years, different applications take different amounts of time to be approved. For example, just because the average approval takes sixteen quarters and a particular petition is filed eight quarters after the generic application was filed, this does not necessarily mean the petition came at the midpoint of the approval process. For example, if this particular generic's total application time was only ten quarters, the petition would have actually come $80 \%$ of the way through the process. Similarly, even if a particular citizen petition was filed two quarters before approval, this would not necessarily be late in the process. If the process had only taken four quarters, two quarters would be the midpoint.

However, it is possible to construct a more relative look at citizen petition timing. We calculated the "Percentage into Pendency," which we defined as a standardized measure of when the citizen petition was filed as a percentage of the overall generic application approval length.

On average, we find that citizen petitions are filed $56.8 \%$ of the way into the pendency of a generic application. In the set of 135 generic application-petition

114. See supra text accompanying notes 61-69. 
pairs used in this calculation, ${ }^{115}$ the average pendency was 17.8 quarters (approximately 4.5 years), and the average citizen petition was filed 9.1 quarteryears into pendency (approximately 2.5 years). In other words, the average citizen petition came roughly halfway through the petition process.

To illustrate, the histogram in Figure VI below shows the number of citizen petitions grouped into the ten deciles between $0 \%$ and $100 \%$ into pendency. For example, the first bar represents all citizen petitions that had a percentage into pendency ranging from $0 \%$ to $10 \%$. The diagonal line in Figure VI illustrates the cumulative percentage of citizen petitions, out of the total 135 citizen petitions, that have fallen into the deciles up to that point. ${ }^{116}$

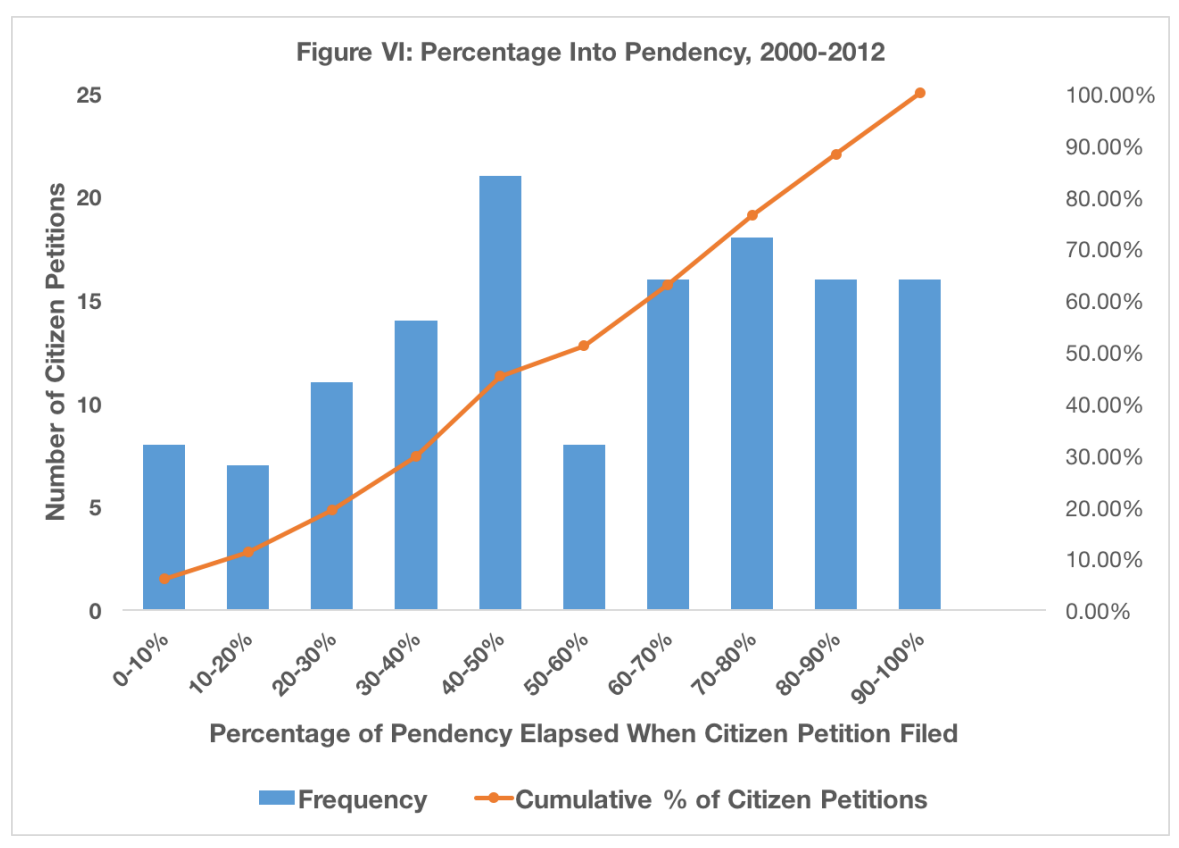

As shown in Figure VI above, about $55 \%$ of petitions were filed more than $50 \%$

115. This calculation was only available if both filing dates and approval dates were available for a generic application, and it was not calculated if the citizen petition was filed before generic application filing, because then the Percentage Into Pendency would be negative, which skews averages and other descriptive statistics. A total of 135 generic application-petition pairs met these criteria, representing $82 \%$ of the petitions for which some data was available.

116. For example, 8 citizen petitions were filed $0-10 \%$ of the way into pendency, and because 8 out of the total 135 petitions constitutes $6 \%$, the line falls at $6 \%$ for the first decile. For the next decile, 7 petitions were filed $10-20 \%$ of the way into pendency. Added onto the 8 petitions from the first decile, the result is 15 out of 135 petitions (11\%) filed $0-20 \%$ of the way into pendency, so the line falls at $11 \%$ for the second decile. 
of the way into pendency, ${ }^{117}$ and $37 \%$ were filed during the last $30 \%$ of pendency. ${ }^{118}$ These findings do not differ significantly from a uniform distribution where each decile would contain $10 \%$ of citizen petitions, although perhaps more notable is that fewer than $30 \%$ of petitions were filed during the first $40 \%$ of pendency.

The key issue, however, is the following. The 2007 Amendments formally require petitioners to declare that the filing was made as soon as the relevant information came to light. Given that the issues mentioned in citizen petitions are often apparent deficiencies in the relevant generic application itself, one might expect to see petitions early in the process if the system were working properly. Thus, we would not expect petition filings to be evenly distributed during pendency. Nor would we expect to see petitions grouped at the midpoint or later on, in the manner seen in Figure VI.

It is also worth noting that the act of filing a citizen petition itself affects the pendency metric. Since a citizen petition can delay generic approval, the citizen petition may extend pendency beyond what would otherwise occur. The result would be the appearance that the citizen petition surfaced earlier in the approval process than it actually did. This effect may be particularly pronounced in the period before the 2007 Amendments, when citizen petitions were not subject to a response deadline and could drag on for long periods of time.

To explore this hypothesis, we once again separated the data into slices before and after the 2007 Amendments. Our results are graphed below in Figures VII and VIII. Figure VII represents our data before the 2007 Amendments, and Figure VIII represents our data after the 2007 Amendments. No major trend appeared for citizen petitions filed before enactment of the Amendments. In this period, the average petition appeared $51.4 \%$ of the way into pendency. Only $47 \%$ of petitions were filed in the last half of generic application pendency, although the most popular category for filing was in the last tenth of pendency (shared with those filed between $40 \%-50 \%$ of the way through approval). ${ }^{119}$

The findings for the period after the 2007 Amendments reveal a stronger trend toward later filing in recent years. This trend offers some validation for the hypothesis that extended review time for citizen petitions skews pendency data for petitions filed before passage of the 2007 Amendments.

As illustrated in Figure VIII below, the average petition during the period after the 2007 Amendments was filed more than $60 \%$ of the way into pendency. ${ }^{120}$ More

117. The number of citizen petitions filed $50-100 \%$ of the way into pendency was 74 out of a total of 135 petitions (55\%).

118. The number of citizen petitions filed $70-100 \%$ of the way into pendency was 50 out of a total of 135 petitions (37\%).

119. In the pre-2007 Amendments period, the number of citizen petitions filed $50-100 \%$ of the way into pendency was 26 out of a total of 55 petitions (47\%). There were 9 citizen petitions filed $90-100 \%$ of the way into pendency, tied with $40-50 \%$ for the most petitions in any individual decile.

120. In the post-2007 Amendments period, the number of citizen petitions filed $60-100 \%$ of the way into pendency was 44 out of a total of 80 petitions (55\%). 
than $42 \%$ of citizen petitions were filed during the final $30 \%$ of generic application approval, and the most common category was those petitions filed $80 \%-90 \%$ through the approval process. ${ }^{121}$ Notably, only $13.8 \%$ of petitions came during the first $30 \%$ of generic application pendency. ${ }^{122}$ It is unlikely to be coincidental that citizen petitions are filed so shortly before generic approval. Nor do the results suggest that competitors filing citizen petitions-many of which claim to have found deficiencies in the generic application-are filing them as soon as the information is uncovered. Finally, the results taken together suggest that the 2007 Amendments have not succeeded in ending the practice of filing citizen petitions to delay generic entry.

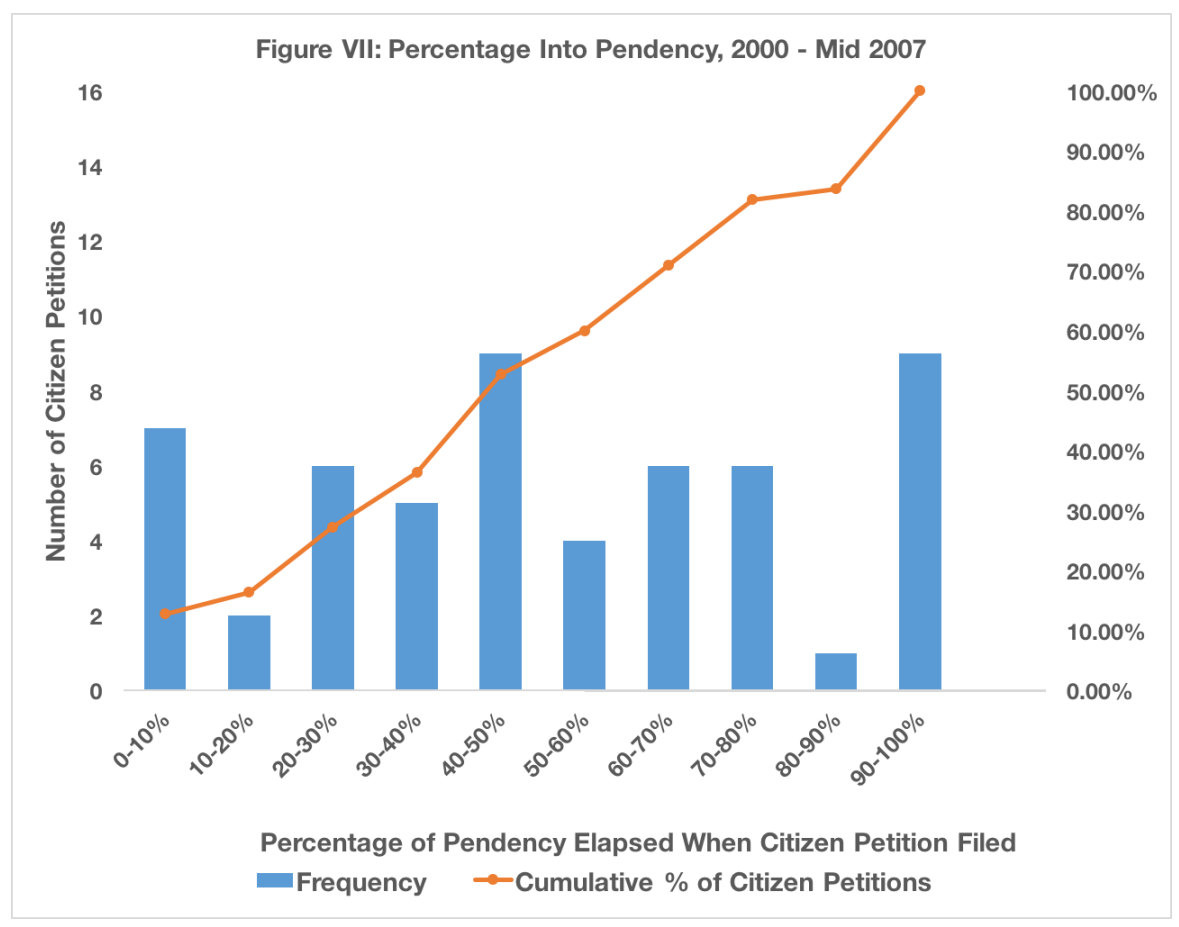

121. In the post-2007 Amendments period, the number of citizen petitions filed 70-100\% of the way into pendency was 34 out of a total of 80 petitions (43\%). There were 15 citizen petitions filed $80-90 \%$ of the way into pendency, the most of any individual decile.

122. In the post-2007 Amendments period, the number of citizen petitions filed $0-30 \%$ of the way into pendency was 11 out of a total of 80 petitions (13.8\%). 


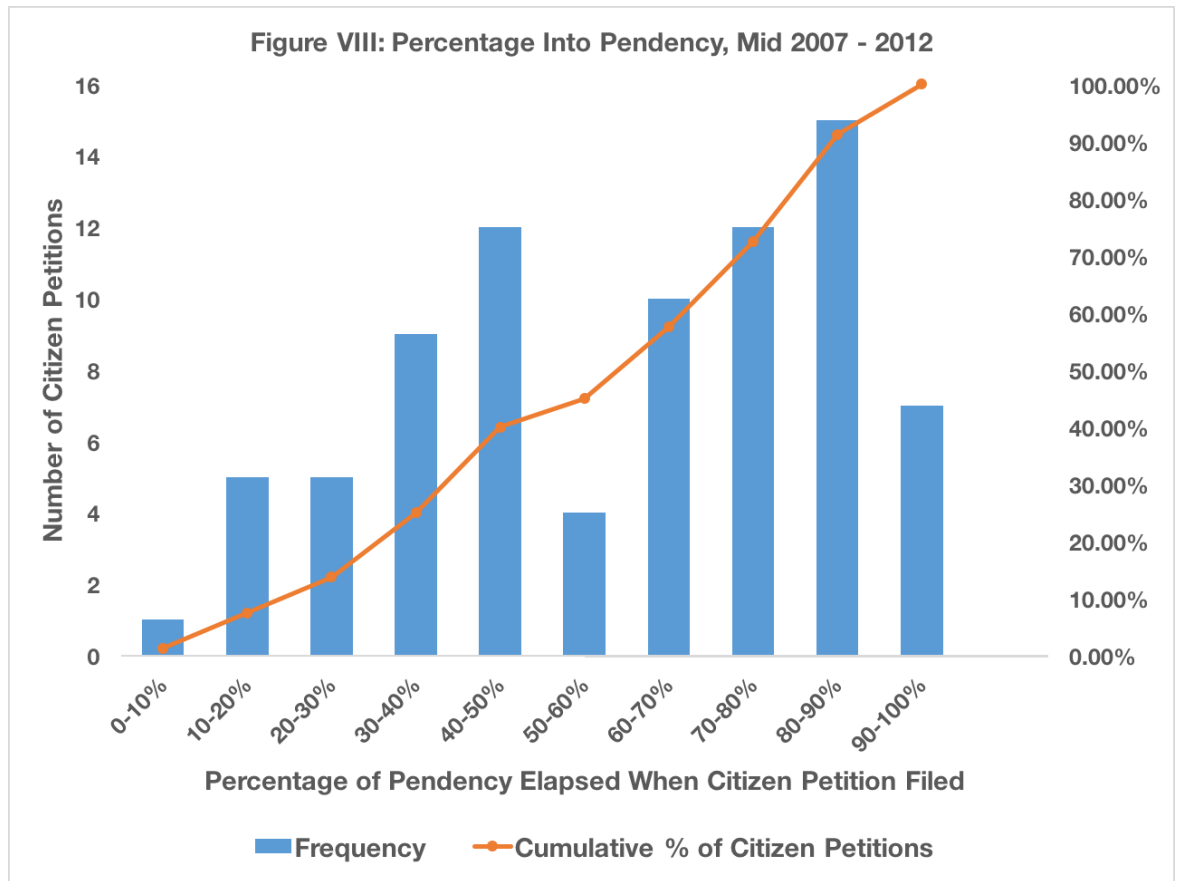

\section{E. Did the 2007 Amendments Do the Job?}

As described above, Congress amended the Food \& Drug Administration Act in 2007 in an effort to prevent citizen petitions from being used to delay generic entry. The 2007 Amendments require the FDA to respond to citizen petitions concerning generic applications within 180 days (shortened to 150 days in 2012); require those filing such petitions to certify that the petition was not intentionally delayed and provide the date when the filer became aware of the concern; and give the FDA the power to summarily deny such petitions in certain circumstances. ${ }^{123}$ Our study suggests that the 2007 Amendments have failed to stem the tide of citizen petitions intended to delay generic entry.

Imposing a deadline of 180 days for the FDA to respond may have reduced the length of the delay, but has by no means deterred the behavior. As detailed above, many competitor petitions continue to be filed late in the game, as a last-ditch effort to hold off competition just a little longer, even though they are unlikely to be successful. The same is likely to be true for the 2012 Amendments, shortening the FDA's deadline to 150 days. The time is slightly shorter, but the incentives remain the same. ${ }^{124}$

123. See supra text accompanying notes 61-68.

124. We cannot draw conclusions about the effects of the 2012 Amendments because our citizen petition data set only covers a time period up to 2012. We limited our search to citizen petitions filed prior to 2013 because test analyses indicated that citizen petitions filed after that 
In particular, the FDA's power to summarily dismiss frivolous petitions appears toothless in application. In its own annual reports, the FDA has mentioned several times that the requirement that the petition both intend to delay generics and raise no valid scientific or regulatory issue is a standard that is "extremely difficult to meet." 125 In fact, as of fiscal year 2014, the FDA had never denied a petition under this provision. ${ }^{126}$

The 2007 Amendments require that the FDA submit an annual report detailing issues related to the $\S 505(\mathrm{q})$ program created by the Amendments. ${ }^{127}$ Although providing only aggregate numbers, the report suggests that the number of citizen petitions that fall within the $\S 505(\mathrm{q})$ program has increased since passage of the Amendments. Although the number has gone up and down along the way, in 2008, the FDA report shows 21 petitions filed, with that number rising to 28 in 2014. Similarly, the number of petitions handled overall by the FDA's Center for Drug Evaluation and Research has increased, from 78 in 2008 to 102 in $2014 .^{128}$ One should note, as well, that the definition of 505(q) petitions does not include all petitions that have the potential to delay generic entry. ${ }^{129}$

The FDA has further complained about "serial petitioning," in which the FDA must respond to multiple petitions submitted sequentially about the same drug, a strategy that can delay approval for a considerable amount of time even though the FDA must respond to each petition within 150 days. ${ }^{130}$ For example, the Federal Trade Commission (FTC) in early 2017 filed an antitrust action against Shire ViroPharma, alleging that the company abused regulatory processes by filing 43 submissions at the FDA (including 24 meritless filings related to a single citizen petition docket) in an effort to hold off generic competition for its gastrointestinal drug, Vancocin. ${ }^{131}$ According to the complaint, the behavior resulted in hundreds

time frequently related to drugs that had not yet been approved, as discussed in Section IV.B.1.

125. U.S. Food \& Drug Admin., Seventh Annual Report on Delays in Approvals of Applications Related to Citizen Petitions and Petitions for Stay of Agency ACtion for FISCAL YEAR 201410 (Aug. 3, 2015), http://www.fda.gov/downloads/AboutFDA /CentersOffices/OfficeofMedicalProductsandTobacco/CDER/ReportsBudgets/UCM464282 .pdf [hereinafter SEVENTH ANNUAL REPORT].

126. Id.

127. 21 U.S.C. $\$ 355(q)(3)$ (2006 \& Supp. I 2007).

128. U.S. Food \& Drug Admin., SeVEnth ANnUAl Report, supra note 125, at 7 n.7. The numbers of overall drug-related petitions, according to the FDA's definition, does not include suitability petitions (defined in Part III) and over-the-counter monograph petitions.

129. See infra text accompanying notes 135-137; see also Carrier \& Wander, supra note 10, at 269 .

130. U.S. Food \& Drug Admin., Seventh Annual Report, supra note 125, at 10.

131. Complaint for Injunctive and Other Equitable Relief, Fed. Trade Comm'n v. Shire ViroPharma, Inc., No. 1:17CV00131 (D. Del Feb. 7, 2017), https://www.ftc.gov/system/files /documents/cases/viropharma_file-stamped_redacted_complaint.pdf [http://perma.cc/D24Z -M5KH] [hereinafter FTC Complaint]; see also Letter from Michel de Rosen, Chief Exec. Officer, ViroPharma, Inc., to Andrew C. von Eschenbach, Acting Comm'r of Food \& Drugs, Div. of Dockets Mgmt., U.S. Food \& Drug Admin., (Mar. 17, 2006), https://www.regulations.gov /docket?D=FDA-2006-P-0007 [http://perma.cc/7S3P-AUFJ] (key citizen petition cited in the FTC's complaint). 
of millions of costs to patients and other purchasers. ${ }^{132}$

In its annual report, the FDA must also show how many generic applications were delayed by citizen petitions. ${ }^{133}$ On its face, the picture looks quite rosy. Of the relevant citizen petitions that the FDA has resolved in seven years of reporting (2008-2014), only six petitions technically resulted in delay under the FDA's definition. ${ }^{134}$ The problem, however, lies in the FDA's definition of a generic application delayed by a citizen petition. First, a citizen petition filed before the relevant generic application is submitted or pending is not subject to $505(\mathrm{q}) .^{135}$ Second, if a generic application is not ready for immediate approval at the 150-day response deadline, the Agency reports no delay. ${ }^{136}$ Thus, the Agency finds no delay even if responding to the petition diverted focus from approving the application, slowing the process. Additional important categories of petitions also are not included under 505(q), including petitions that relate to the six-month exclusivity for the first generic filer or petitions about one's own application. ${ }^{137}$ Painted this way, the citizen petition picture does not look so rosy.

In short, all of the trends we observed were stronger when examining the period after the 2007 Amendments in isolation. Part of this difference is likely due to the fact that the 180-day response deadlines enacted in the 2007 Amendments mean that some petitions are rejected more quickly. Thus, the period from citizen petition submission to generic approval is not stretched out as much by petitions as it often was before the 2007 reforms. However, considering we also found that generic application pendency has not decreased since the 2007 Amendments-and may have actually increased-it appears that the reforms have not led to a systematic decrease in the length of time to get a generic application to market. Avoiding delay, of course, was the goal of the 2007 Amendments. Finally, the number of delayrelated petitions has not decreased over time, according to both our own analysis and the FDA's classification of $\S 505(\mathrm{q})$ petitions. ${ }^{138}$

132. FTC Complaint, supra note 131 , at 2 .

133. 21 U.S.C. $\$ 355(q)(3)$ (B) (2006 \& Supp. I 2007).

134. U.S. Food \& Drug Admin., SEVEnth ANnUAl Report, supra note 125, at 8-9.

135. Brendan Coffman, WSGR Alert: Citizen Petitions Aimed at Delaying Generic Competition Remain a Concern 1 (Feb. 11, 2015), https://www.wsgr.com/publications /PDFSearch/wsgralert-citizen-petitions.pdf [http://perma.cc/43ZF-ALK9].

136. U.S. FoOd \& DRUG ADMIN., SEVEnTH ANNUAL REPORT, supra note 125, at 9.

137. 505(q) GUIDANCE, supra note 82, at 4; see also 21 U.S.C. $\$ 355(\mathrm{q})(4)$.

138. In November of 2016, the FDA promulgated a new rule on citizen petitions, strengthening some of the language and requirements, as well as ever so slightly widening the number of petitions that must make certifications, by requiring certifications on petitions that "may" be subject to $\$ 505(\mathrm{q})$. See Amendments to Regulations on Citizen Petitions, Petitions for Stay of Action, and Submission of Documents to Dockets, 81 Fed. Reg. 78500 (Nov. 8, 2016) (codified at 21 C.F.R. pt. 10). However, while the petition filer will have to make certifications to this new category, the provisions of $\S 505(\mathrm{q})$, such as the 150 -day response requirement, will not apply. As the FDA explains in the Federal Register discussion, "If there is no related ANDA, $\S 505(\mathrm{~b})(2)$ application, or $351(\mathrm{k})$ application pending at the time the petition is submitted, then the requirements of $\S 10.31$ will apply to the petition, but we will not consider the provisions of $\S 505(\mathrm{q})$ of the FD\&C Act to apply to the petition." See id. 
These findings do not mean that $\S 505(\mathrm{q})$ has been totally ineffective. The 180 day (and later 150-day) response deadlines for petitions certainly prevent any one citizen petition from extending the generic approval process for a significant amount of time, a huge improvement over the days when petitions could be pending for years. ${ }^{139}$ Nevertheless, while the possible magnitude of abuse may have been curbed, the amount of abuse that is taking place does not seem to have declined. Many petitions are still filed very late in the approval process, the number of petitions has not declined, and there is evidence that petitions are filed even later after the passage of the 2007 Amendments. If a petition still manages to hamper the FDA for a few months, that delay or slowing of the generic approval process can still be worth hundreds of millions of dollars in unfettered monopoly sales.

While the 2007 Amendments may have reduced the length of the delay, they have failed to stop the tactic. As long as the benefits of 6 months of delay (180 days) can be worth hundreds of millions of dollars, companies will be tempted to follow this path, and consumers will continue to pay the price. A different approach is needed.

\section{THE ROAD AHEAD}

As described in the prior section, the citizen petition process has been hijacked by pharmaceutical companies as a route to frustrate generic approvals. We find evidence that many citizen petitions are not filed as soon as potentially worrisome information about a drug is discovered, but are instead filed near the later stages of the generic approval process. Nearly half of delay-related citizen petitions between 2000 and 2012 were filed within a year and half of generic approval. In fact, $46 \%$ of the petitions in the post-2007 Amendments period were filed within a year of final approval of the generic drug, and 24\% were filed within 6 months. This suggests that these petitions were some of the last barriers standing in the way of approval for some generics. Our data shows that the average citizen petition in the period after the 2007 Amendments was filed more than $60 \%$ of the way through the generic application's pendency, with more than $40 \%$ filed during the last $30 \%$ of pendency.

Also troubling is that citizen petitions appear to be the main catalyst and foundation for attempting many other obstructionist delay strategies. As Feldman and Frondorf have documented, pharmaceutical companies are increasingly focusing their efforts to head off generic competition, using obstruction tactics involving administrative processes. Such tactics include skirmishes over drug labels and inserts, as well as using a safety program known as REMS (Risk Evaluation and Mitigation Strategies) to refuse to give generic companies samples of the branded

139. See Carrier \& Wander, supra note 10, at 285-86 (detailing a citizen petition process that delayed the introduction of a generic version of the insomnia drug Ambien for more than 3 years at a cost of $\$ 3.1$ billion). 
drug necessary for demonstrating bioequivalence in the approval process. ${ }^{140}$ Many of these delay tactics operate through the citizen petition process, with pharmaceutical companies filing citizen petitions demanding that generic applicants use different labels or risk mitigation strategies, for example. ${ }^{141}$ Thus, citizen petitions are now a key pathway through which pharmaceutical companies attempt to make changes and raise concerns (often spurious ones) to obstruct or delay generic approval. At the moment, the FDA appears powerless to stop it, but what pathways would be more effective?

Looking at the nature of the problem, one could imagine three types of approaches to curb the behavior of filing citizen petitions to delay generic entry. These might include 1) a simple prohibition on competitors filing citizen petitions related to generic entry, if one were to conclude that most behavior represented by this type of petition is likely to be inappropriate; 2 ) procedural blocks to ensure that the behavior cannot create suboptimal results; or 3) punitive measures as a deterrent. The section below describes each and sets out mechanisms for accomplishing the goals. The details of the mechanism are less important, however, than choosing among the pathways and identifying the proper incentive structures and the optimal institutional actors.

\section{A. A Simple Prohibition}

The simplest approach for curbing abuse of the citizen petition process would be to prevent competitors from filing citizen petitions related to generic applications. This would be analogous to the per se rules in antitrust. If one concludes that the vast majority of behavior within a certain category is likely to be improper, societal resources may be better served by declaring the category per se off limits, rather than weighing each instance.

Thus, in the antitrust context, the Supreme Court has noted that

$[\mathrm{t}]$ he rationale for per se rules in part is to avoid a burdensome inquiry into actual market conditions in situations where the likelihood of anticompetitive conduct is so great as to render unjustified the costs of determining whether the particular case at bar involves anticompetitive conduct. ${ }^{142}$

Similarly, one author has described the limitations on patentable subject matter by explaining that, "with certain categories of patents, so few things within that space are likely to survive scrutiny that we cordon off the area for all." 143

140. For a detailed discussion of these practices, see Feldman \& Frondorf, supra note 3, at 534; see also The CREATES ACT: Ending Regulatory Abuse, Protecting Consumers, and Ensuring Drug Price Competition: Hearing Before the $S$. Comm. on the Judiciary Subcomm. on Antitrust, Competition Policy \& Consumer Rights, 114th Cong. 58 (2016) (testimony of Robin Feldman discussing abuse of the REMS safety protocol process) (transcript on file with author) [hereinafter CREATES ACT Testimony].

141. See Feldman \& Frondorf, supra note 3, at 543-54.

142. Jefferson Par. Hosp. Dist. No. 2 v. Hyde, 466 U.S. 2, 15 n.25 (1984).

143. FELDMAN, supra note 21 , at 99 (describing the limitations on patentable subject matter 
This approach carries a certain cynicism regarding the likelihood that companies would have society's best interests in mind when commenting on whether the FDA should trust their competitors to enter the market. It is a little like the fox offering to guard the henhouse. ${ }^{144}$ The incentives are not well-aligned with the desired outcome. Nevertheless, although banning competitors from filing citizen petitions is a simple approach, it is also simplistic. Pharmaceutical companies are likely to argue that, as the actors in the field most familiar with a drug, they are in the best position to sound the alarm when problems are on the horizon. Nor would this approach necessarily be fully effective. Companies could still submit generalized citizen petitions before any generic applications are filed or file petitions that have the effect of delaying entry-for example, by asking the FDA to reconsider all labeling related to the drug-without specifically requesting a delay.

\section{B. Procedural Blocks}

An alternative approach would involve enacting procedural blocks to channel the behavior into positive, rather than suboptimal, results. In other words, one might wish to preserve the citizen petition process for all-including competitorsand yet ensure that citizen petitions filed by competitors do not delay generic entry.

For example, one might direct that citizen petitions filed by competitors must be filed within a year of when the generic company files for approval. ${ }^{145}$ Given that the average length of time for a generic application is approximately four years, citizen petitions filed within a year are less likely to delay final approval.

Similarly, when competitors raise an issue related to the drug in general, the rule could be that the generic application goes forward on a timeline unrelated to the citizen petition. In other words, the generic can receive approval, and whatever issue is raised can be resolved after that approval, if necessary. After all, the branded drug remains on the market under the current requirements for the drug, which suggests that the issues raised in the citizen petition are not of such magnitude that the drug cannot be offered to the public. Thus, whatever issues must be resolved would be resolved as to all forms of the drug-generic and brand-name-on a timeline unrelated to the generic's approval. One could refer to this as the "band plays on" rule. Even for issues related to whether the generic is bioequivalent or satisfies the FDA's requirements, one could once again conclude that the Agency is generally the best judge of that-at least with issues so serious that approval must be denied.

One concern is that, although most citizen petitions are denied, some are granted. This suggests that occasionally, legitimate issues are at stake, and safety

in patent law).

144. See CREATES ACT Testimony, supra note 140 (transcript of statement of Robin Feldman, using fox analogy in response to a senator's question).

145. This would require that the FDA make all generic applications public and easily searchable when they are filed. 
must remain the FDA's primary focus. Looking at concerns from the other direction, a "band plays on rule" still may squander some societal resources. The FDA must spend time responding to each concern raised. Similarly, branded companies could still use the tactic of filing citizen petitions to raise their rivals' costs. ${ }^{146}$ In other words, generic competitors conceivably could be forced to spend time and money responding to spurious issues raised. Nevertheless, with the prospect of delayed entry off the table, such a procedural block could substantially decrease a brand-name company's incentives to engage in this behavior. Of the choices discussed here, this may, indeed, be the most effective.

\section{Punitive Deterrents}

The third approach would be to adopt some form of punitive measure designed to deter abuse of the citizen petition process, either through the courts or the FDA. Thus, parties that engage in behavior to try to block or delay generic entry through citizen petitions could be subject to a penalty calibrated to deter all but the hardiest of souls from engaging in the behavior in the first place.

In contemplating this approach, the initial question would involve determining the proper adjudicatory body to task with deciding whether the behavior falls beyond bounds. In theory, one might suggest that the FDA is the proper adjudicatory body. After all, the FDA has the greatest expertise for evaluating whether the issues raised in a citizen petition are spurious or wellfounded.

The FDA, however, has proven more effective at evaluating patient safety than party behavior. Since 2007, the Agency has had the power to summarily deny any petition filed with the primary purpose of delaying generic approval if the petition does not also raise valid scientific or regulatory issues. ${ }^{147}$ As noted above, the FDA had not used the provision even once through fiscal year 2014. It is certainly possible that a differently worded authority would prompt greater activity from the Agency. Nevertheless, one could argue that such a role may not be the right fit. The FDA may be better suited to evaluate science-related bad behavior than competition-related bad behavior.

An alternative would be to provide greater power for competition authorities (such as the Federal Trade Commission (FTC) or the Department of Justice (DOJ)) or third party actors (such as the competitors who suffer harm) to act against anticompetitive behavior involving citizen petitions. In general, however, antitrust actions are slow and expensive. ${ }^{148}$ Moreover, if the experience with pay-for-delay settlements is a guide, by the time the courts slowly begin choking off the behavior,

146. See generally Thomas G. Krattenmaker \& Steven C. Salop, Anticompetitive Exclusion: Raising Rivals' Costs to Achieve Power over Price, 96 YALE L.J. 209 (1986) (seminal work identifying ability of competitors to impose costs on rivals without similarly incurring such costs).

147. See 21 U.S.C. $\$ 355(\mathrm{q})(1)$ (E) (2012).

148. See generally Feldman, Ending Patent Exceptionalism, supra note 25, at 63, 72. 
pharmaceutical companies will have altered their tactics. ${ }^{149}$ Antitrust law simply may not be sufficiently nimble.

Most importantly, providing an effective antitrust pathway for challenging citizen petitions will require substantial shifts in doctrines related to antitrust and regulatory agencies. The Noerr-Pennington line of cases, dating back to the 1960s, establishes the general principle that one has the right to petition the government without fear of antitrust liability. Although antitrust liability may still attach if one's petition to the government is judged to be a "sham," the bar for establishing a sham petition is extremely high. ${ }^{150}$

Certain types of citizen petition actions could be even more difficult to attack under antitrust law. For example, if citizen petitions are used to prevent a generic hopeful from obtaining samples of the branded product-which the generic needs in order to demonstrate that its drug is bioequivalent-antitrust actors trying to challenge the behavior would also run up against Trinko. ${ }^{151}$ In the Trinko opinion, the Supreme Court all but shut the door on antitrust actions that claim a party's competitor has improperly refused to sell to it. In general, competitors are not required to sell to each other, and as the Department of Justice has argued, refusals to deal or "forced sharing" rarely helps consumers in the long run. ${ }^{152}$ Although providing samples for generic approval may be the rare exception to the rule, getting past Trinko would be difficult.

In short, Congress or the Supreme Court would have to be willing to alter antitrust doctrines in a manner sufficient to allow antitrust actors to bring successful litigation-without, of course, breaking the bank in the process. A punitive measure that costs exorbitant amounts to administer will have very little deterrent effect.

\section{Transparency}

No approach is a perfect or permanent solution. Fixing abuse of the citizen petition pathway may require a combination of these approaches. Moreover, recent history has shown that when the legal system closes off one pathway, pharmaceutical companies search for others. ${ }^{153}$ Thus, whatever paths and

149. See Feldman \& Frondorf, supra note 3, at 516.

150. See generally Robin Feldman, Federalism, First Amendment \& Patents: The Fraud Fallacy, 17 Colum. SCI. \& TECH. L. REV. 30 (2015) (discussing the history of the NoerrPennington doctrine and its operation in practice).

151. See Verizon Comm. Inc. v. Law Offices of Curtis V. Trinko, LLP, 540 U.S. 398 (2004).

152. See U.S. Dep't of Justice, Competition and Monopoly: Single-Firm Conduct UNDER SECTION 2 OF THE SHERMAN ACT 119-29 (2008), https://www.justice.gov/sites/default /files/atr/legacy/2009/05/11/236681.pdf [http://perma.cc/LQH7-Y4SF]; see also Geoffrey Manner, Senator Lee's Prescription for Regulatory Failure in the Generic Drug Market, TRUTH ON THE MARKET (June 14, 2016), https://truthonthemarket.com/2016/06/14/senator-lees -prescription-for-regulatory-failure-in-the-generic-drug-market [http://perma.cc/6HXQ -VTCR] (describing Trinko as an impediment to antitrust cases regarding refusals to provide samples to generic applicants).

153. See generally Feldman \& Frondorf, supra note 3 . 
approaches are chosen to curb citizen petition abuse, it will be critical to ensure that regulators, legislators, and the courts can spot new techniques as they emerge. A little sunshine goes a long way.

In particular, greater transparency from the FDA could be tremendously effective in exposing new drug pricing schemes early on. Although the FDA makes a wealth of information publicly available, there are significant gaps in the system. For example, as described in the methodology section, there is no systematic way to find the date on which a generic application was filed. One could argue that all generic applications should be posted when filed, along with the date of their filing, and that the public should not have to wait until the generic is approved to discover that information, if it even appears in the approval letter. As it stands now, the more effective a drug company is at blocking generic competition, the longer that company has before the public can see what is being done.

At the very least, however, once a generic application has been approved, the public should be able to easily tell when the application was filed. Specifically, all approval letters should be posted on the FDA website, and the FDA website should always list filing and approval dates for every generic- online and not just in these letters.

Unfortunately, the FDA appears to be moving in the opposite direction and lessening transparency. For our study, we were able to extract filing dates from some of the approval letters that the FDA posted and backfill many others through our estimation technique when the FDA approval letters did not mention the filing date. The FDA recently changed its protocols, however, so that the public will no longer be able to do even that. According to one report, the FDA has initiated a new protocol in which it will omit from approval letters any mention of the filing date of the original generic application. ${ }^{154}$

Other basic information could improve transparency as well, including more complete labeling of citizen petitions themselves, and full information on generic application numbers and how they are assigned. Finally, the massive Freedom of Information Act (FOIA) backlog at the FDA also operates to mask improper behavior. When we inquired for our research, Agency personnel were wonderfully helpful but noted that FOIA requests are taking approximately two years for a response.

Making full data on generic applications quickly and clearly available to the public is essential for curbing inappropriate behavior. Particularly if the FDA is not assigned the full task of policing competition, other actors-including state and federal regulators, legislators, academic researchers, public interest groups, and generics companies themselves-must have easy access to the relevant information. Transparency efforts such as these-along with the types of prohibitions, procedural blocks, or punitive measures approaches described above-are essential for curbing attempts to delay generic competition through citizen petitions. Without such endeavors, we will continue to see a citizen's process diverted to the

154. See Pollock, supra note 91. 
service of pharmaceutical companies playing games to hold off generic entry as long as possible. Consumers, of course, pay the price. 